\title{
STUDIUM TECHNOLOGICZNE MATERIAŁÓW KRZEMIENNYCH ZE STANOWISKA WOŁKUSZ 3 W PÓŁNOCNO-WSCHODNIEJ POLSCE. KONCEPCJA PRODUKCJI OSTRZY PREFERENCYJNYCH
}

\author{
TECHNOLOGICAL STUDY OF LITHIC MATERIALS \\ FROM SITE WOŁKUSZ 3 IN NORTH-EASTERN POLAND. \\ CONCEPT OF PREFERENTIAL POINT PRODUCTION
}

\begin{abstract}
Abstrakt: W artykule przedstawiono pierwszą część wyników studium technologicznego inwentarza zabytków krzemiennych kultury wołkuszańskiej. Zostało ono oparte na potencjale interpretacyjnym metody składanek, obserwacjach morfologicznych oraz analizie reliefu negatywowego. Badaniom poddano homogeniczny, liczący ponad dwa tysiące przedmiotów zespół ze stanowiska $\mathrm{nr} 3 \mathrm{w}$ Wołkuszu. O wyborze tego inwentarza zadecydował fakt występowania w jego obrębie dystynktywnego dla tej jednostki taksonomicznej zestawu narzędzi, rdzeni oraz produktów debitażu. W pracy skoncentrowano się na omówieniu jednej z dwóch zrekonstruowanych w toku analizy strategii eksploatacyjnych - określonej jako koncepcja produkcji ostrzy preferencyjnych.
\end{abstract}

Słowa kluczowe: paleolit schyłkowy, młodszy dryas, krąg kultur z liściakami, kultura wołkuszańska, analiza technologiczna inwentarzy krzemiennych, stanowisko Wołkusz 3

\begin{abstract}
Author presents the first part of the results of a technological study of Volkushian flint artefacts. The research is based on the interpretative potential of the refitting method, morphological observations, as well as scar pattern and superposition analysis. A homogeneous group of over two thousand flints from site 3 in Wołkusz has been examined. The choice of this inventory was determined by the fact that it contained distinctive set of tools for this taxonomic unit, that is cores and debitage. The article focuses on discussing one of two technological strategies which was reconstructed in the course of the analysis, defined as the concept of preferential point production.
\end{abstract}

Keywords: Late Palaeolithic, Younger Dryas, tanged points complex, Volkushian culture, lithic technological analysis, Wołkusz site no. 3

${ }^{a}$ Dr Michał Przeździecki, Instytut Archeologii, Uniwersytet Warszawski, Krakowskie Przedmieście 26/28, 00-927 Warszawa, m.przezdziecki@uw.edu.pl, ORCID iD: https://orcid.org/0000-0002-8605-3941. 


\section{WSTĘP}

Celem artykułu jest prezentacja pierwszej części wyników analizy technologicznej inwentarza krzemiennego ze stanowiska nr $3 \mathrm{w}$ Wołkuszu, gm. Lipsk nad Biebrzą, pow. augustowski, woj. podlaskie. Obejmuje ona szczegółową charakterystykę jednej z dwóch zrekonstruowanych strategii technologicznych, którą określono jako koncepcję produkcji ostrzy preferencyjnych.

Niniejszy tekst jest niewielkim, istotnie skróconym i zmodyfikowanym fragmentem rozprawy doktorskiej, w której podjęto próbę całościowej charakterystyki krzemieniarstwa kultury wołkuszańskiej, rozumianego jako wewnętrznie spójny pakiet typologicznych oraz technologicznych atrybutów, odróżniających zespoły tej jednostki od inwentarzy innych kultur schyłkowopaleolitycznego kręgu z liściakami (Przeździecki 2014). Na poziomie szczegółowym realizacja tak zarysowanego celu badań oznaczała konieczność odpowiedzi na szereg pytań cząstkowych, wyznaczających zarazem kolejne etapy analizy. Najważniejsze z nich to: 1. zdefiniowanie, opartego na obserwacjach typologicznych, dystynktywnego zestawu form przewodnich (narzędzi); 2. zdefiniowanie, opartego na rekonstrukcji procesu debitażu, zgeneralizowanego wzorca zabiegów technologicznych; 3. identyfikacja materialnych korelatów tych zabiegów, zapisanych w określonych typach i parametrach wytworów; 4. ocena kwestii współwystępowania oraz powtarzalność przyjętego zestawu cech typologicznych i technologicznych na różnych stanowiskach; 5. ocena rangi taksonomicznej powyższych ustaleń.

Klucz do realizacji tych założeń stanowiła - wyznaczająca jednocześnie pierwszy etap badań - szczegółowa analiza inwentarza „reperowego" ze stanowiska nr 3 w Wołkuszu. O wyborze tego zespołu zadecydował fakt współwystępowania w jego obrębie, z jednej strony pełniącego rolę „typologicznej kotwicy” kompletnego zestawu form narzędziowych, uznawanych za charakterystyczne dla kultury wołkuszańskiej (Szymczak 1995, s. 13, 14, 30-36), z drugiej zaś reprezentatywnej grupy rdzeni i produktów debitażu (wióry, odłupki, łuski), umożliwiających przeprowadzenie studiów technologicznych.

Drugi etap badań polegał na porównaniu wniosków sformułowanych podczas analizy inwentarza reperowego $\mathrm{z}$ wynikami badań innych zespołów, położonych na wschód od Wisły, charakteryzujących się obecnością liściaków bez retuszu spodniej strony trzonka.

\section{LOKALIZACJA STANOWISKA I HISTORIA BADAŃ}

Stanowisko nr $3 \mathrm{w}$ Wołkuszu odkryte zostało przez Karola Szymczaka podczas badań powierzchniowych w 1979 r. Tworzyło je pojedyncze skupisko zabytków krzemiennych zlokalizowane na południowej terasie rzeki Wołkuszanki, około $50 \mathrm{~m}$ na północny zachód od dużego zgrupowania punktów osadnictwa paleolitycznego i mezolitycznego oznaczonego jako stanowisko nr 5 (ryc. 1). Obecnie niemal cały obszar tego kompleksu jest praktycznie niedostępny do obserwacji archeologicznej. 


\section{INTRODUCTION}

The objective of this article is to present the first part of the results of a technological analysis of a flint assemblage from site no. 3 in Wołkusz, Lipsk nad Biebrzą municipality, Augustów county, Podlachian Voivodeship. It illustrates a detailed characteristics of one of two reconstructed technological strategies, which was described as a concept of preferential point production.

This text is a short, significantly abbreviated and modified fragment of a $\mathrm{PhD}$ dissertation which attempted to provide a comprehensive characteristics of flint industry of the Volkushian culture understood as a coherent package of typological and technological attributes which distinguished assemblages of this unit from assemblages of other cultures belonging to the Late Palaeolithic circle with tanged points (Przeździecki 2014). The pursuit of thus defined research objective at the level of details required answers to a series of questions which, in turn, indicated successive steps in the analysis. The most important issues include: 1. definition of a distinctive set of index forms (tools) on the basis of typological observations; 2. definition of a generalized pattern of technological procedures on the basis of reconstructed process of debitage; 3 . identification of material correlates of these procedures reflected in particular types and parameters of lithic products; 4 . evaluation of the presence of these forms and frequency of occurrence of the defined set of typological and technological features at various sites; 5 . evaluation of the taxonomic significance of the aforementioned results.

A detailed analysis of the "referential" inventory from site no. 3 in Wołkusz was the key to achieve these goals and at the same time it was the first step in the research. This assemblage was selected due to the fact that it contained a complete set of tool forms regarded as characteristic for the Volkushian culture, which served as a "typological anchor" (Szymczak 1995, pp. 13, 14, 30-36), as well as a representative group of cores and debitage products (blades, flakes, chips), which made it possible to conduct a technological analysis.

The next step involved a comparison of conclusions drawn in the course of the analysis of the "referential" inventory with other assemblages, recovered from an area east of the Vistula River, characterized by the presence of tanged points without retouch on the ventral part of the tang.

\section{LOCATION AND HISTORY OF RESEARCH AT THE SITE}

Site no. 3 in Wołkusz was discovered by Karol Szymczak in the course of a surface survey in 1979. It consisted of a single concentration of flint artefacts, situated on the south fluvial plain along the Wolkuszanka River, approx. $50 \mathrm{~m}$ to the northwest of a big concentration of Palaeolithic and Mesolithic settlement relics, described as site no. 5 (Fig. 1). There is practically no access to the whole area of the complex for archaeological observation at the moment. However, at the time of the initial stages of research the area was completely exposed and particular concentrations of flint 


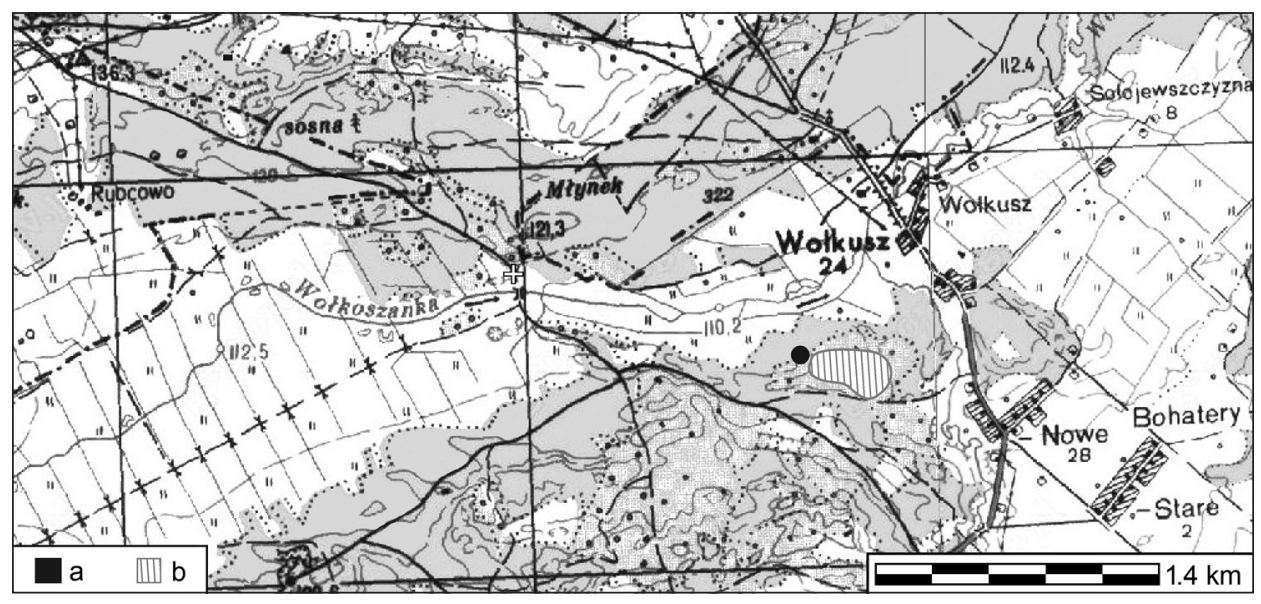

Ryc. 1. Lokalizacja punktów osadnictwa paleolitycznego i mezolitycznego w Wołkuszu a - stanowisko nr 3; b - stanowisko nr 5 .

Opracował M. Przeździecki

Fig. 1. Location of the Palaeolithic and Mesolithic settlement in Wołkusz a - site no. $3 ; \mathrm{b}$ - site no. 5 .

Prepared by M. Przeździecki

Niemniej w momencie rozpoczynania badań teren ten był zupełnie odsłonięty, a poszczególne krzemienice odwiane i doskonale czytelne. Artefakty występowały na kulminacji oraz skłonie niewielkiej, silnie zdegradowanej, wydmy, tworząc na jej powierzchni wyraźną koncentrację o eliptycznym kształcie i wymiarach około $10 \mathrm{~m} \times 7 \mathrm{~m}$. W $1985 \mathrm{r}$. na stanowisku przeprowadzono badania wykopaliskowe, $\mathrm{w}$ trakcie których rozpoznano obszar $36 \mathrm{~m}^{2}$, pozyskując przy tym bogaty inwentarz, składający się z 2814 zabytków krzemiennych.

W jego obrębie wyróżnić możemy dwa odmienne pod względem cech typologicznych, technologicznych oraz stanu zachowania zespoły: schyłkowopaleolityczny (wołkuszański), reprezentowany przez 2801 artefaktów (99,6\% znalezisk), oraz mezolityczny (północno janisławicki), stanowiący ewidentną i łatwą do wyróżnienia domieszkę liczącą zaledwie 13 elementów ( $0,4 \%$ znalezisk).

\section{CHARAKTERYSTYKA MATERIAŁU ŹRÓDŁOWEGO}

Przedmiotem studiów jest, stanowiący pozostałość pracowni krzemieniarskiej - spójny pod względem stylistycznym, technologicznym, surowcowym (wszystkie okazy wykonane zostały z kopalnianej odmiany krzemienia północno-wschodniego), jak i stanu zachowania (występowanie delikatnej, żółtej patyny oraz grubej, pozbawionej śladów erozji kory) - inwentarz krzemienny kultury wołkuszańskiej z eponimicznego stanowiska tej jednostki Wołkusz $3^{1}$. Homogeniczność inwentarza

${ }^{1}$ Omawiany zespół nie stanowił wcześniej przedmiotu odrębnego opracowania i znany jest jedynie z ogólnego opisu w pracy o charakterze syntetycznym (Szymczak 1995, s. 32, 33). 
artefacts were visible on the surface. The artefacts were found at the top and on the slope of a relatively small and strongly eroded dune; they formed a conspicuous concentration of an ellipsoid shape and dimensions of approx. $10 \mathrm{~m} \times 7 \mathrm{~m}$. In 1985 the site was excavated and an area of $36 \mathrm{~m}^{2}$ was explored. The remarkable inventory recovered in that season consisted of 2814 flint artefacts.

Two assemblages of material which differs in terms of typological and technological features as well as state of preservation can be distinguished within the recovered inventory: Late Palaeolithic (Volkushian culture), represented by 2801 specimens (99.6\%) and Mesolithic one (North Janisławice culture), which was an obvious and easily identified intrusion, consisting of merely 13 artefacts $(0.4 \%)$.

\section{FEATURES OF THE MATERIAL}

The analysed sources come from a flint inventory of the Volkushian culture, discovered at the eponymous site of this culture - Wołkusz $3^{1}$. The material consists of remains of a lithic workshop and displays consistency in terms of style, technology, raw material (all forms were made of a mined variety of north-eastern flint) and the state of preservation (presence of fine yellow patina and thick cortex devoid of erosion marks). The homogeneity of the inventory is additionally emphasized by a high frequency of refits - 200 items, formed by combining 640 artefacts, i.e. nearly $23 \%$ of the recovered pieces. Due to the location of the site on a dune (resulting in the absence of preserved stratigraphic clues or organic matter which could be dated), the chronology of the assemblage was established on the basis of typological arguments. The taxonomic classification of the artefacts, accepted by the discoverer of the site, was based on the combined presence of certain types of tool forms - tanged points without retouch on the ventral surface of the tang (Fig. 2a-d), burins (Fig. 2f, g, i-k), particularly transversal specimens (Fig. 2j, k) and nucleiform ones (Fig. 2i), end-scrapers (Fig. 2h) and truncated pieces with fine retouch (Fig. 2e).

One of the most important results of the analysis is the distinguishing of two different technological strategies, which, nevertheless, share certain common features. These strategies are described as a concept of production of preferential points and a concept of production of arranged blades. The identified differences are connected with the aim of production, type and sequence of completed technological procedures and the group of material correlates generated as a result. This article discusses the first of these two concepts, connected with sourcing of blades compliant with strictly defined morphometric parameters, which seem to have been used for production of tanged points.

The direct arguments for distinguishing this technological strategy were delivered by the results of analysis of four refits of cores described as blocks: W3B1

1 The assemblage has not been a subject of a detailed monograph and is known only from a general description in a review (Szymczak 1995, pp. 32, 33). 
znajduje dodatkowe potwierdzenie w wysokiej frekwencji ponad 200 składanek, w ramach których łącznie udało się scalić 640 wytworów, tj. niemal 23\% znalezisk. Ze względu na wydmowy charakter stanowiska (brak zachowanej stratygrafii oraz możliwych do datowania materiałów organicznych), atrybucja chronologiczna zespołu oparta została na argumentach typologicznych. Podstawę przyjętej klasyfikacji taksonomicznej omawianych znalezisk stanowiło dla ich odkrywcy współwystępowanie określonych typów form narzędziowych - liściaków trzpieniowatych bez retuszu spodniej strony trzonka (ryc. 2a-d), rylców (ryc. 2f, g, i-k), w tym głównie okazów poprzecznych (ryc. 2j, k) i rdzeniokształtnych (ryc. 2i), drapaczy (ryc. 2h) oraz drobno retuszowanych półtylczaków (ryc. 2e).

Jednym z najważniejszych efektów studiów przeprowadzonych przez autora jest wyróżnienie w badanym zespole dwóch odrębnych, choć spiętych wspólnym mianownikiem strategii technologicznych, określonych jako: koncepcja produkcji ostrzy preferencyjnych oraz koncepcja produkcji wiórów aranżowanych. Zidentyfikowane różnice dotyczą zarówno celu produkcji, rodzaju oraz sekwencji podejmowanych działań technologicznych, jak i zestawu generowanych w ich efekcie materialnych korelatów. W niniejszym artykule omówiona została pierwsza z tych koncepcji, związana z pozyskiwaniem półsurowca o ściśle określonych parametrach morfometrycznych, przeznaczonego, jak się wydaje, do produkcji liściaków.

Bezpośrednich argumentów do wyróżnienia tej strategii technologicznej dostarczyły wyniki analizy czterech składanek rdzeni określonych jako bloki: W3B1 (ryc. 3-5), W3B6 (ryc. 6; 7), W3B10 (ryc. 8; 9) oraz W3B28 (ryc. 10; 11). Ze względu na ograniczoną objętość tekstu jej szczegółowe omówienie oparto na formule studium przypadku, najbardziej reprezentatywnego okazu W3B1. Zdefiniowany w ten sposób pakiet danych i obserwacji został następnie zestawiony z ogólnymi charakterystykami pozostałych bloków.

\section{CHARAKTERYSTYKA METOD BADAWCZYCH}

Studium technologiczne wymienionych bloków oparte zostało na obserwacjach określonego zestawu detali morfometrycznych oraz układu i sekwencji negatywów (ang. scar pattern and superposition analysis) (np. Bar-Yosef, Van Peer 2009, s. 105, 106; Perreault i in. 2013; Pastoors i in. 2015). Istotną część stanowiły także wnioski formułowane na podstawie składanek (np. Cziesla 1990; Fitting rocks... 2007), niestety w przypadku rdzeni związanych z koncepcją produkcji ostrzy preferencyjnych, dość rzadkie (zazwyczaj dwu-, trzyelementowe).

W swym zasadniczym kształcie analizy skoncentrowane zostały na trzech aspektach: 1. rekonstrukcji łańcucha operacji technicznych związanych z procesem debitażu poszczególnych bloków; 2 . syntezie pozyskanych informacji w ramach zgeneralizowanego wzorca zachowań technologicznych na stanowisku; 3. powiązaniu poszczególnych kategorii form oraz ich atrybutów morfologicznych z określonymi typami działań. 

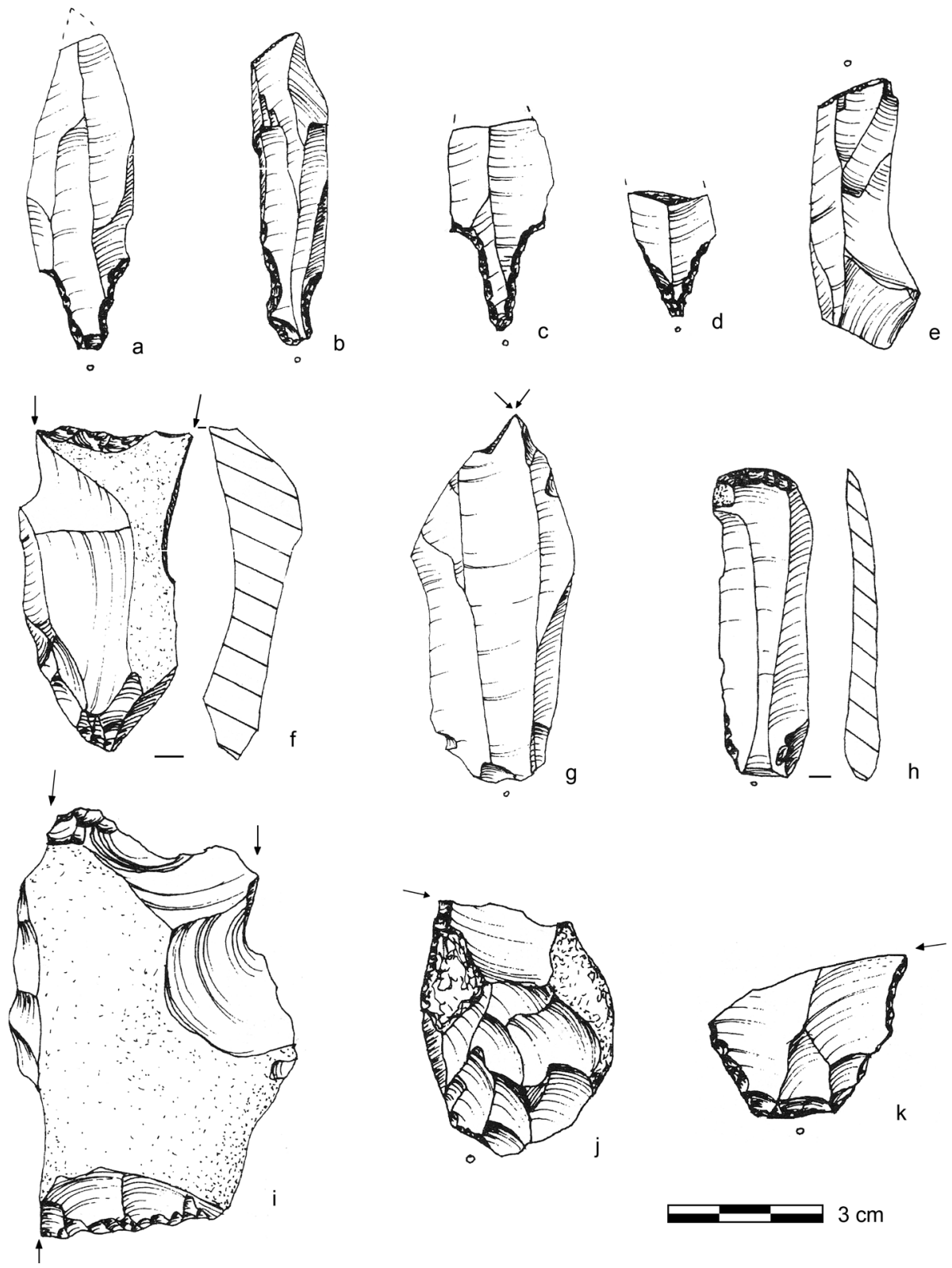

Ryc. 2. Stanowisko Wołkusz 3, wybór narzędzi krzemiennych

a-d - liściak; e - półtylczak; f - rylec węgłowy; g - rylec klinowy; $\mathrm{h}$ - drapacz; i - rylec rdzeniokształtny; $\mathrm{j}, \mathrm{k}$ - krępy rylec poprzeczny.

Opracowali M. Przeździecki i G. Czajka, na podstawie pracy K. Szymczaka (1995, tabl. X 2, 3; XI 2-4; XII 1, 3-7)

Fig. 2. Site Wołkusz 3, selection of flint tools

$\mathrm{a}-\mathrm{d}$ - tanged point; $\mathrm{e}$ - truncated piece; $\mathrm{f}$ - burin on truncation; $\mathrm{g}$ - dihedral burin; $\mathrm{h}$ - end-scraper; $\mathrm{i}$ - nucleiform burin; $\mathrm{j}, \mathrm{k}$ - short transversal burin.

Adapted from K. Szymczak (1995, Pl. X 2, 3; XI 2-4; XII 1, 3-7) by M. Przeździecki and G. Czajka 


\section{STUDIUM PRZYPADKU - BLOK W3B1}

Blok W3B1 (ryc. $3 ; 4)$ to dwuelementowa składanka wióra o charakterystycznym, zawiasowo wyklinowanym wierzchołku (ang. hinge) oraz dwupiętowego rdzenia wiórowego o szerokiej odłupni, krawędziowych bokach i płaskim tyle /e. 1/2. Uwagę zwracają wyraźnie krępe proporcje okazu (wysokość - $77 \mathrm{~mm}$, szerokość - $75 \mathrm{~mm}$, grubość - $33 \mathrm{~mm}$ ) oraz jego dyskoidalna forma, podkreślana przez dwustożkowy, a przy tym nieco owalny zarys odłupni.

Najwcześniejszy, możliwy do zrekonstruowania etap eksploatacji związany był z zaprawą pięty górnej (głównej) ukształtowanej za pomocą dwóch precyzyjnych odbić /n. 1, 2/ oraz zaprawą dolnej (pomocniczej) uformowanej serią radykalnych odbić, zakończonych głębokimi, następującymi po sobie zawiasami /n. 3/. Wyraźnie odmienny sposób ukształtowania obu płaszczyzn, związany z ich różną funkcją, znajduje bezpośrednie odzwierciedlenie w takich atrybutach jak: 1. pole powierzchni - płaszczyzna pięty dolnej jest ponad trzykrotnie mniejsza od górnej; 2. charakter powierzchni - płaszczyzna pięty górnej jest równa, zaś dolnej nieregularna; 3. długość krawędzi na styku z odłupnią - w przypadku pięty górnej zbliżona do maksymalnej szerokości odłupni, w przypadku dolnej ograniczona do niewielkiego fragmentu jej części centralnej; 4. kąt rdzeniowy - ostry w przypadku pięty górnej (około $65^{\circ}$ ), zbliżony do prostego w przypadku pięty dolnej (około $85^{\circ}$ ).

Bardziej skomplikowana jest kwestia rekonstrukcji działań związanych z zaprawą odłupni, brakuje bowiem elementów bezpośrednio ilustrujących inicjalne stadium tego procesu. Jedynym świadectwem są szczątkowe fragmenty negatywów /n. 4-7/. Niemniej, warto zwrócić uwagę na kilka dość ważnych faktów przybliżających kontekst oraz sposób realizacji tych działań: płaszczyzna odłupni zaplanowana została na szerszym boku konkrecji, pomimo braku obiektywnych ograniczeń dla innej lokalizacji; ekspozycja odłupni/praodłupni prowadzona była w sposób zmierzający do wykształcenia w jej centralnej części silnie wysklepionej, izolowanej strefy, "podciętej” z dwóch stron przez głębokie negatywy /n. 8, 9, 13/; większość odbić wyprowadzona została od strony pięty górnej, która już na tym etapie wydaje się mieć charakter dominujący (pięta główna).

Ostatni epizod działań łączonych z zaprawą ilustruje grupa enigmatycznych negatywów na lewym boku rdzenia /n. 10-12/, stanowiących ślad po zabiegu kształtowania dwuściennego zatępiska.

Kolejny etap eksploatacji związany jest ze skomplikowaną procedurą pozyskiwania półsurowca. W jej ramach możemy wydzielić dwie zasadnicze fazy: trójstopniowy proces kształtowania (konfiguracji) formy celowej na odłupni (projektowanie jej wykroju) oraz finalny zabieg oddzielenia ostrza. Podstawę takiej interpretacji stanowi występowanie na odłupni dwóch kategorii negatywów różnych pod względem morfologii, położenia oraz pełnionej funkcji. Pierwszy typ reprezentuje para szerokich negatywów oddzielonych od strony pięty górnej, zlokalizowanych wzdłuż

${ }^{2}$ Podane między ukośnikami liczby odpowiadają przedstawionym na schematycznych rysunkach bloków oznaczeniom negatywów (skrót n....) oraz elementom składanki (skrót e....). 
(Figs 3-5), W3B6 (Figs 6; 7), W3B10 (Figs 8; 9) and W3B28 (Figs 10; 11). Owing to the text length limitations, its detailed description is based on the case study of the most representative specimen - W3B1. The package of data and observations compiled in this way was then compared with general descriptions of the other blocks.

\section{DESCRIPTION OF RESEARCH METHODS}

The technological analysis of the aforementioned blocks was based on observation of a defined group of morphometric details as well as scar pattern and superposition analysis (e.g. Bar-Yosef, Van Peer 2009, pp. 105, 106; Perreault et al. 2013; Pastoors et al. 2015). Conclusions formed on the basis of analysis of refits are an important contribution (e.g. Cziesla 1990; Schurmans, De Bie eds. 2007), however, they are relatively rare in the case of cores associated with the concept of preferential point production (usually connected with two- or three-piece specimens).

The analyses focused on three aspects: 1 . reconstruction of the chaîne opératoire connected with the process of debitage of particular blocks; 2 . compilation of the information with regards to a generalized technological behaviour pattern at the site; 3 . association of different form categories and their morphological attributes with certain types of procedures.

\section{CASE STUDY - BLOCK W3B1}

Block W3B1 (Figs 3; 4) is a blade refit consisting of two elements, with a characteristic hinge and a double-platform blade core with a wide flaking surface, edged sides and a flat back /e. $1 / 22$. The features which deserve attention are the clearly robust proportions of the specimen (height $-77 \mathrm{~mm}$, width $-75 \mathrm{~mm}$, thickness $-33 \mathrm{~mm}$ ) as well as its disc-shaped form, emphasized by the bi-conical and slightly oval contour of the flaking surface.

The earliest stage of knapping that was possible to reconstruct was connected with the preparation of the upper striking platform (the main one) shaped with two precise removals /n. 1, 2/ and preparation of the lower (auxiliary) striking platform, shaped by means of a series of radical removals, finished with deep hinges, following one after another $/ \mathrm{n}$. 3/. The obviously different manner of shaping of the two surfaces, associated with their different functions, is directly reflected in the following attributes: 1. surface area - the surface of the lower striking platform is three times smaller than the surface of the upper one; 2 . features of the surface - the surface of the upper striking platform is quite even, while the surface of the lower one is irregular; 3. length of the edge adjacent to the flaking surface - in the case of the upper striking platform it is close to the maximum width of the flaking surface while in the case

2 The numbers provided between slashes correspond with negatives (abbreviated as $\mathrm{n} . .$. ) and elements (abbreviated as e....) of the refits represented in the diagrams. 


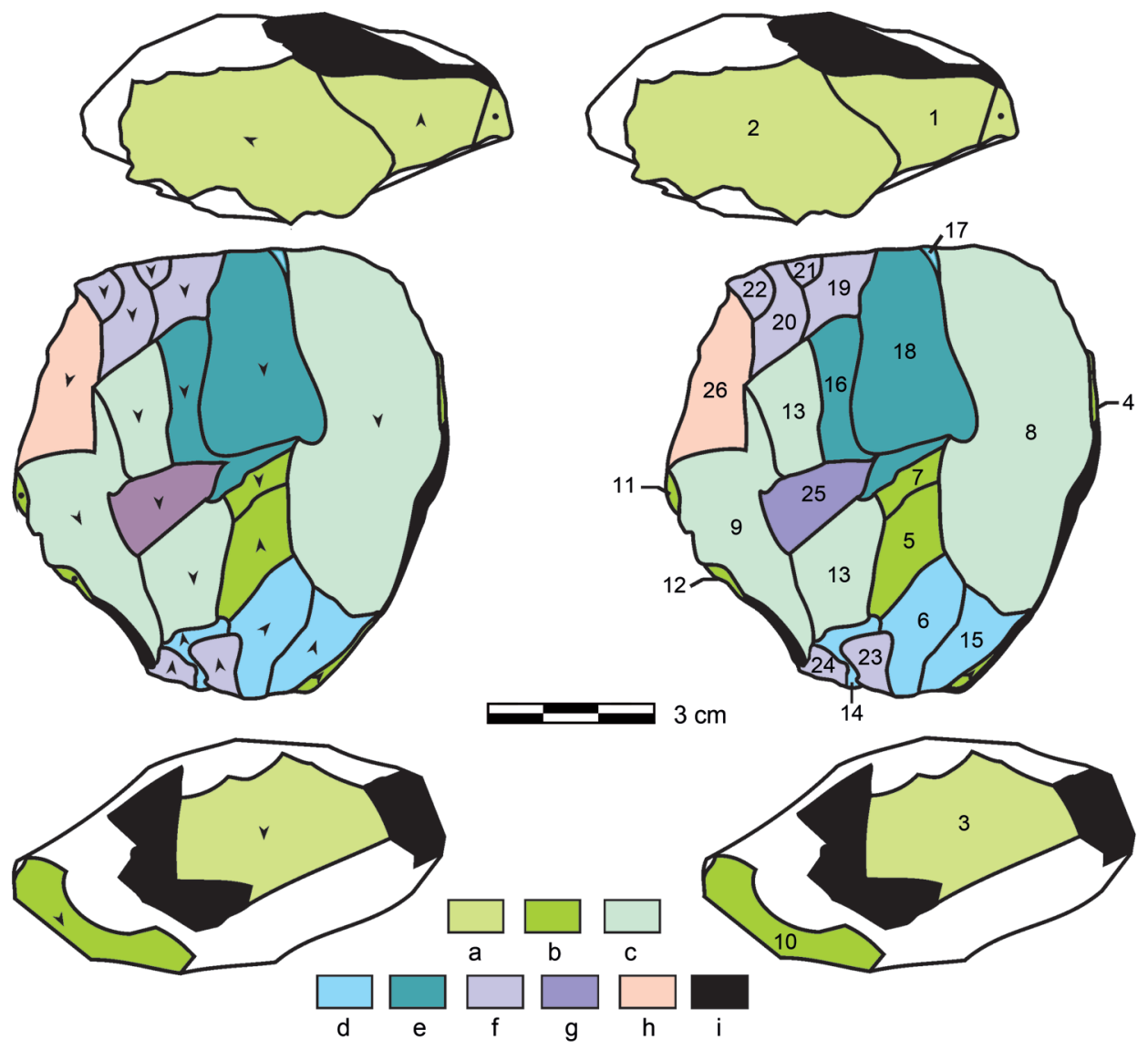

Ryc. 3. Schemat ilustrujący proces debitażu bloku W3B1

a - zaprawa wstępna pięty; b - zaprawa wstępna odłupni, boków oraz tyłu; c - generowanie ostrza „pierwszej serii", izolacja krawędzi bocznych; d - izolacja wierzchołka i podstawy; e - odbicie ostrza; $\mathrm{f}$ - generowanie ostrza „drugiej serii”, izolacja wierzchołka i podstawy; g - odbicie ostrza „drugiej serii”; h - negatywy odbić o charakterze doraźnym (niezwiązane z pierwotną koncepcją eksploatacyjną); i - powierzchnie korowe.

Opracowali M. Przeździecki i G. Czajka

Fig. 3. Diagram illustrating the debitage process of block no. W3B1

$\mathrm{a}$ - preliminary preparation of the striking platform; $\mathrm{b}$ - preliminary preparation of the flaking surface, sides and back of the core; $\mathrm{c}$ - production of the "first series" point, side edges isolation; $\mathrm{d}$ - distal end and base isolation; $\mathrm{e}$ - execution of the point; $\mathrm{f}$ - production of the "second series" point, distal end and base isolation; $\mathrm{g}$ - execution of the "second series" point; $\mathrm{h}$ - negatives of removals of the expedient character (unconnected with the original debitage concept); i - cortical surfaces.

Prepared by M. Przeździecki and G. Czajka

prawego oraz lewego skraju odłupni /n. 8, 9, 13/ (ryc. 5a) ${ }^{3}$. Ich obecność związana jest z fazą izolacji krawędzi bocznych formy celowej. Drugą kategorię śladów odzwierciedla kompleks drobnych (krótkich i wąskich) negatywów /n. 6, 14-15/,

${ }^{3}$ W przypadku negatywu /n. 13/ nie można wykluczyć interpretacji, zgodnie z którą stanowi on ślad po oddzieleniu wcześniejszego ostrza (ryc. 5a). 

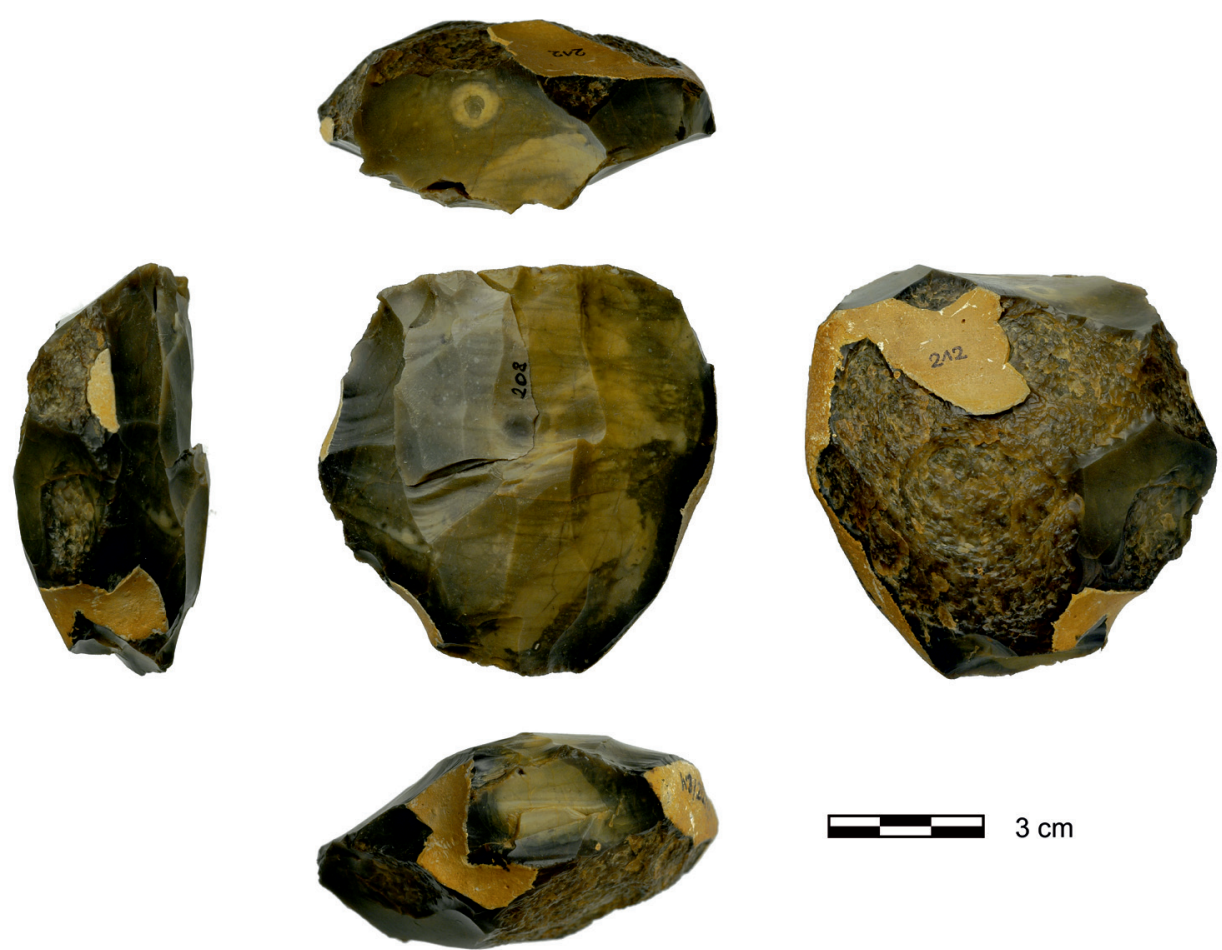

Ryc. 4. Blok W3B1 - dwuelementowa składanka rdzenia.

Fot. M. Przeździecki

Fig. 4. Block W3B1 - two-element refitting of a core.

of the lower one it is limited to a small fragment of its central part; 4. flaking angle - acute in the case of the upper striking platform (approx. $65^{\circ}$ ) and close to the right one in the case of the lower striking platform (approx. $85^{\circ}$ ).

The issue of reconstruction of procedures connected with the preparation of the flaking surface is more complicated due to the absence of elements which would directly illustrate the initial stage of this process. Fragments of negatives /n. 4-7/ are the only evidence. Nevertheless, a few quite important facts suggesting the context and manner of implementing these procedures should be considered: the flaking surface was planned on the wider side of the concretion despite the absence of objective limitations for other locations; the isolation of the flaking/pre-flaking surface was conducted in a manner leading to the shaping of an isolated, markedly elevated area in its central part, "undercut" on two sides by deep negatives /n. 8, 9, 13/; most removals were made from the side of the upper striking platform, which seems to have been the dominant one (main striking platform) already at this stage.

The final procedures associated with the preparation are reflected in the cluster of enigmatic negatives on the left side of the core /n. 10-12/, which are marks of the shaping of a two-wall crest. 

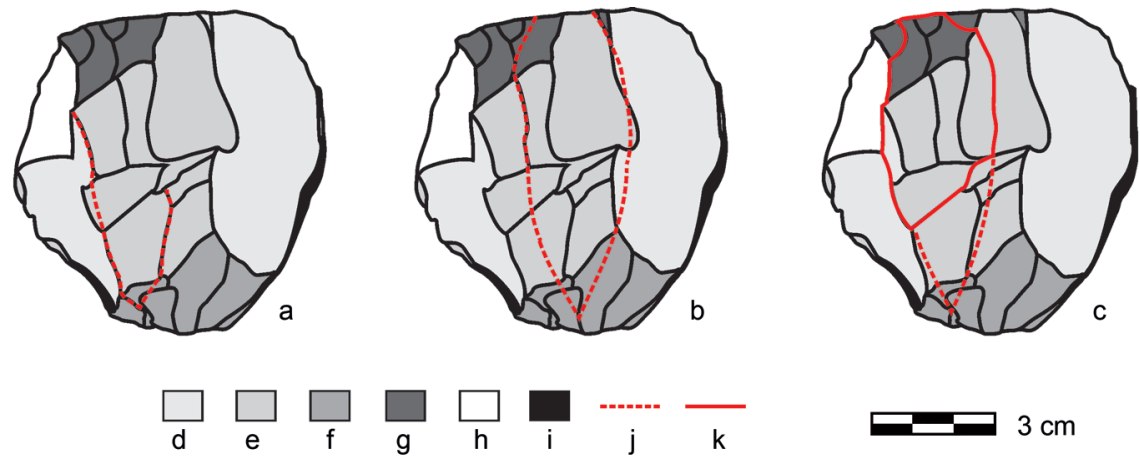

$3 \mathrm{~cm}$

Ryc. 5. Lokalizacja oraz przybliżony zarys form celowych zaplanowanych w procesie redukcji bloku W3B1

a - hipotetyczne „ostrze pierwszej serii”; b - „ostrze pierwszej serii”; c - „ostrze drugiej serii”; d - negatywy izolujące krawędzie boczne ostrza; e - negatywy strefy izolacji (powierzchnia negatywowa ostrza); f - negatywy wiórków korekcyjnych (izolacja wierzchołka ostrza); g - negatywy wiórków (izolacja podstawy ostrza); h - negatywy odbić o charakterze doraźnym (niezwiązane z pierwotną koncepcją eksploatacyjną); i - powierzchnie korowe; $j$ - rekonstrukcja na podstawie składanek; $\mathrm{k}$ - rekonstrukcja na podstawie superpozycji negatywów.

Opracowali M. Przeździecki i G. Czajka

Fig. 5. Localization and a rough outline of the intended forms pre-planned in the reduction process of block no. W3B1

a - hypothetical "first series point"; b - "first series point"; c - "second series point"; $\mathrm{d}$ - negatives of side edges isolation; $\mathrm{e}$ - negatives of the isolation area (dorsal surface of the point); $\mathrm{f}$ - negatives of correction bladelets (isolation of the distal end of the point); $\mathrm{g}$ - negatives of bladelets (isolation of the base); $\mathrm{h}$ - negatives of removals of expedient character (unconnected with the original debitage concept); $i$ - cortical surfaces; $j$ - reconstruction based on refittings; $\mathrm{k}$ - reconstruction based on superposition analysis of the negatives.

Prepared by M. Przeździecki and G. Czajka

o charakterystycznym wachlarzowatym układzie, oddzielonych od strony pięty dolnej. Stanowią one efekt oddzielenia serii wiórków korekcyjnych mających za zadanie wyodrębnienie na odłupni wierzchołka planowanego ostrza. Grupa tych działań określona została mianem fazy izolacji wierzchołka. Kulminacyjny punkt procesu generowania formy celowej, tj. fazę oddzielenia ostrza, ilustruje negatyw /n. 16/.

Mimo szeregu podjętych przez wytwórcę działań finał zrekonstruowanej sekwencji operacyjnej zakończył się niepowodzeniem. Nastąpiło to najprawdopodobniej w wyniku nieprawidłowego przyłożenia siły uderzenia, czego efektem było niekontrolowane wyklinowanie się wióra mniej więcej w połowie wysokości odłupni /n. 16/. Powtórną próbę oddzielenia „ostrza”, co ciekawe, poprzedzoną zabiegiem izolacji jego strefy proksymalnej /n. 17/, ilustruje negatyw /n. 18/. Niestety i ona zakończyła się niepowodzeniem, dodatkowo prowadząc do powstania głębokiego zawiasu.

Kolejną grupę działań dokumentuje zespół negatywów /n. 19-25/ oraz składanka wióra /e. 2/ z rdzeniem /e. 1/. Stanowiły one powtórzenie zrekonstruowanej wcześniej sekwencji operacyjnej, obejmującej proces kształtowania i oddzielenia „ostrza pierwszej serii” (ryc. 5b). Forma, którą określić możemy mianem „ostrza drugiej serii", została zaplanowana z lewej strony pierwotnej strefy izolacji, tam, gdzie wysklepienie odłupni było największe, a jednocześnie w miejscu, gdzie zawiasy były 
The next stage of reduction is associated with the complex process of shaping the target form. It can be divided into two main steps: a three-step process of the shaping (configuration) of the target form on the flaking surface (shaping of its outline) and the final removal of the point. This interpretation is based on the presence of two categories of negatives on the flaking surface, which differed in terms of morphology, location and function. The first type is represented by a couple of wide negatives removed from the side of the upper striking platform, located along the right and left edges of the flaking surface /n. 8, 9, 13/ (Fig. 5a) ${ }^{3}$. Their presence is connected with the step of isolation of the lateral edges of the target form. Another category of marks comprises a group of small (short and narrow) negatives $/ \mathrm{n}$. 6 , 14-15/ aligned in a characteristic fan-shaped pattern, separated from the side of the lower striking platform. They are a result of removal of a series of correction bladelets in an attempt to isolate the distal end of the predetermined point on the flaking surface. The series of these procedures was called the step of isolation of the distal end. The highlight of the process of generation of the target form, i.e. the step of isolation of the point is illustrated by negative /n. 16/.

Despite the series of actions undertaken by the knapper, the conclusion of the reconstructed chaîne opératoire was a failure. Most likely it resulted from an incorrect force of impact and, as a consequence, uncontrolled formation of a hinge roughly in the mid-height of the flaking surface /n. 16/. Another attempt at separation of the "point", preceded with a procedure of isolation of its proximal part $/ \mathrm{n} .17 /$, is illustrated by negative /n. $18 /$. It also failed and additionally led to the emergence of a deep hinge.

Another sequence of procedures is documented by a group of negatives /n. 19-25/ and a refit of the blade/e. 2/ from the core /e. 1/. These procedures were a repetition of the previously reconstructed chaîne opératoire, which consisted of the shaping and removal the "first series point" (Fig. 5b). The form which could be described as the "second series point" was planned on the left of the original area of separation, where the convexity of the flaking surface was the most marked and at the same time in the area where the hinges were the shallowest (Fig. 5c). The procedure of separation of the point was "by standard" preceded by a sequence of predetermining actions: isolation of the distal end, illustrated by two negatives aligned in a characteristic wedge-shaped pattern /n. 23, 24/ as well as removal of two correction bladelets with an aim of isolation of the proximal part of the predetermined point /n. 19-22/. In this case, the final procedure of separation of the target form also ended in failure /e. 2, n. 25/, again leading to the emergence of a hinge and as a result, further deterioration of the flaking surface.

The final procedure of reduction of the W3B1 core is illustrated by a single negative $/ \mathrm{n} .26 /$, which is a mark of removal of a blade of an undefined function.

The summary of the analysis should be started with an attempt at a generalization and organization of the reconstructed actions in the chaîne opératoire.

${ }^{3}$ In the case of negative /n. 13/, it is also possible that it is a mark left after removal of an earlier point (Fig. 5a). 
najpłytsze (ryc. 5c). „Standardowo” zabieg oddzielenia „ostrza” poprzedził zestaw działań predeterminujących, obejmujących: operację izolacji wierzchołka, ilustrowaną przez dwa negatywy o charakterystycznym, klinowatym układzie /n. 23, 24/, oraz zabieg oddzielenia dwóch drobnych wiórków korekcyjnych, mających na celu izolację części proksymalnej planowanego ostrza /n. 19-22/. Także w tym przypadku finalny zabieg oddzielenia formy celowej zakończył się fiaskiem /e. 2, n. 25/, po raz kolejny prowadząc do powstania zawiasu, a w efekcie dalszej degradacji odłupni.

Ostatni akt obróbki rdzenia W3B1 ilustruje pojedynczy negatyw /n. 26/, stanowiący pozostałość po oddzieleniu wióra o bliżej nieokreślonej funkcji.

Podsumowanie powyższej analizy warto zacząć od próby generalizacji i uporządkowania zrekonstruowanych działań w ramach łańcucha operacji.

W procesie eksploatacji bloku W3B1 wyróżnić możemy trzy główne stadia: etap zaprawy wstępnej, obejmującej w pierwszej kolejności powierzchnię pięt, następnie odłupni, na końcu zaś, i to tylko w niewielkim zakresie, boki oraz tył rdzenia. Zdecydowanie priorytetową rolę odgrywała procedura przygotowania odłupni, obejmująca nie tylko usunięcie kory, ale także wykształcenie w jej centralnej części wyraźnie wyodrębnionej (wypukłej) strefy, „podciętej” z dwóch stron przez szerokie negatywy wiórów oddzielone wzdłuż krawędzi na styku odłupni oraz boków rdzenia.

Kolejne stadia definiowane są przez dwa następujące po sobie etapy: konfiguracji i oddzielenia „ostrza pierwszej serii” oraz konfiguracji i oddzielenia „ostrza drugiej serii”. Należy zaznaczyć, iż w obu przypadkach proces generowania form celowych miał taki sam, wyraźnie ustandaryzowany, cztero- lub trójfazowy przebieg, obejmujący: 1. izolację krawędzi bocznych ostrza (dowód - szerokie negatywy na prawym i lewym skraju odłupni); 2. izolację wierzchołka (dowód - seria krótkich negatywów wiórkowych o wachlarzowatym układzie oddzielonych od strony pięty dolnej); 3. izolację podstawy (dowód - krótkie, bardzo drobne negatywy wiórkowe oddzielone od strony pięty górnej); 4. oddzielenie ostrza (dowód - laurowaty negatyw formy celowej w centralnej części odłupni, powodujący w tym miejscu jej wyraźne wypłaszczenie).

W świetle przestawionej interpretacji seria trzech pierwszych działań ma charakter zabiegów technicznych/przygotowawczych, w których efekcie generowana jest specyficzna kategoria form, tzw. predeterminujących, np. szerokie wióry podkorowe związane z kształtowaniem zasadniczego zarysu wypukłości na odłupni czy drobne, szerokowierzchołkowe (trapezowate) wiórki lub wióroodłupki związane z konfiguracją części dystalnej projektowanego „ostrza”. Z kolei oddzielona w finalnej fazie forma preferencyjna reprezentuje kategorię debitażu predeterminowanego (ang. predetermined lub pre-planned debitage; Inizan i in. 1992, s. 46, 47; Bradley, Giria 1996, s. 23-26; Dziewanowski 2012).

Podejmując próbę zdefiniowania najważniejszych atrybutów morfologicznych rdzeni eksploatowanych w ramach omawianej koncepcji, należy zwrócić uwage na: 1. dymorficzny charakter pięt, gdzie jedna jest precyzyjnie ukształtowana, a jej szerokość pokrywa się mniej więcej z szerokością odłupni, druga zaś jest nieregularna i obejmuje tylko niewielki fragment powierzchni odbić; 2. płaską odłupnię o elipsoidalnym (dwustożkowym) zarysie, wysklepioną w części centralnej, 
Three main stages can be distinguished in the process of reduction of block W3B1: the stage of preliminary preparation, initially including the surfaces of the striking platforms, then the flaking surface and finally, to a rather limited degree, the sides and back of the core. The procedure of preparation of the flaking surface was the most important part. It involved not only the removal of the cortex, but also the shaping of a clearly visible (convex) area in its central part, "undercut" on two sides by wide negatives of blades, separated along the contact lines between the flaking surface and sides of the core.

The subsequent phases are defined by two successive stages: configuration and separation of the "first series point" as well as configuration and separation of the "second series point". It should be noted that in both cases the process of generation of target forms followed the same, clearly standardized, four- or three-step pattern involving: 1. isolation of the lateral edges of the point (evidence - wide negatives on the left and right sides of the flaking surface); 2. isolation of the distal end (evidence - a series of short blade negatives aligned in a fan-shaped pattern, separated from the side of the lower striking platform); 3. isolation of the base (evidence - short, very fine bladelet negatives separated from the side of the upper striking platform); 4. removal of the point (evidence - laurel leaf-shaped negative of the target form in the central part of the flaking surface, which resulted in an obvious flattening in this area).

In the light of this interpretation, the series of the first three actions is a sequence of technical/preparatory procedures. They generate a particular category of the so-called predetermining forms, e.g. wide sub-cortical blades associated with the shaping of the basic contour of the bulge on the flaking surface, or with bladelets and blade-flakes with broad (trapezoid) tops connected with the configuration of the distal end of the planned "point". The preferential form separated in the final step represents the category of predetermined debitage (Inizan et al. 1992, pp. 46, 47; Bradley, Giria 1996, pp. 23-26; Dziewanowski 2012).

In an attempt to define the most important morphological attributes of cores reduced according to the described concept, attention should be paid to: 1. dimorphism of striking platforms, with one which is precisely shaped and its width is roughly equal to the width of the flaking surface, while the other striking platform is irregular and includes only a minor part of the surface of reduction; 2. flat flaking surface of ellipsoid (bi-conical) contour, convex in the central portion, characterized by a particular wedge-shaped scar pattern of negatives displaying various morphologies, as well as alignment and direction of removals; 3 . flat or slightly convex back and sides emphasizing the disc-shaped form of the core.

\section{COMPARATIVE ANALYSIS}

The production procedures and morphological features identified as a result of analysis of core $\mathrm{W} 3 \mathrm{~B} 1$ display marked analogies in the other three blocks.

One of them, W3B6 (Figs 6; 7), is a three-part refit of two chunks /e. 1, 3/ which form an almost complete double-platform core with a wide flat flaking surface of 
charakteryzującą się specyficznym, klinowatym reliefem negatywów o zróżnicowanej morfologii, układzie oraz kierunku odbić; 3. płaski lub lekko wypukły tył oraz krawędziowe boki podkreślające dyskoidalną formę rdzenia.

\section{ANALIZA PORÓWNAWCZA}

Zdefiniowany, w wyniku analizy rdzenia W3B1, zestaw zabiegów wytwórczych oraz cech morfologicznych ma ścisłe analogie w charakterystyce trzech innych bloków.

Pierwszy z nich, W3B6 (ryc. 6; 7), to trójelementowa składanka dwóch okruchów /e. 1,3/ tworzących niemal kompletny rdzeń dwupiętowy o szerokiej, płaskiej i eliptycznej w zarysie odłupni /e. 1, 3/ oraz odnawiaka z przygotowania pięty górnej /e. 2/.

Najwcześniejsza możliwa do zrekonstruowania grupa operacji związana jest z zaprawą powierzchni tylnej. Fakt, że ilustrujące ten proces negatywy/n. 1-5/ nie mają zachowanych partii proksymalnych, sugeruje bardzo wczesną metrykę tych działań. Świadczy też o silnej redukcji pierwotnych rozmiarów bryły.
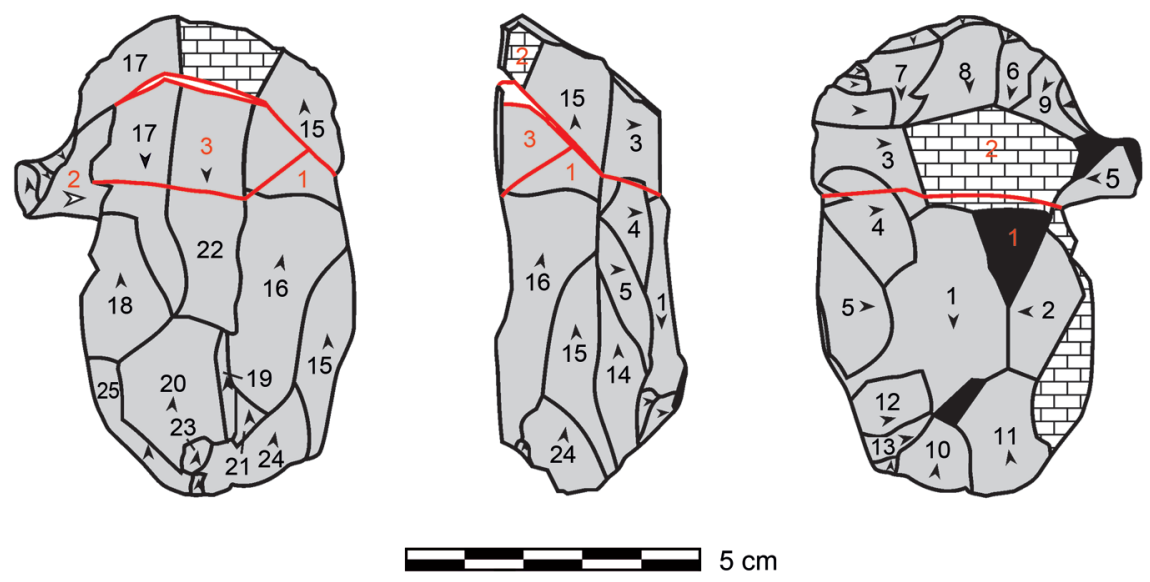

$5 \mathrm{~cm}$
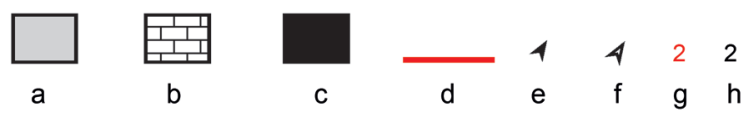

Ryc. 6. Blok W3B6

a - powierzchnie negatywów; b - powierzchnie zdegradowane (odpryski termiczne); c - powierzchnie korowe; d - linie połączeń między elementami; e - oznaczenie kierunku odbicia na powierzchni negatywowej; f - oznaczenie kierunku odbicia na powierzchni pozytywowej; g - numer elementu w składance; h - numer negatywu.

Opracował M. Przeździecki

Fig. 6. Block W3B6

$\mathrm{a}$ - surfaces of the negatives; $\mathrm{b}$ - degraded surfaces (thermal cracks); $\mathrm{c}$ - cortical surfaces; $\mathrm{d}$ - lines connecting the elements; $\mathrm{e}$ - indication of the direction of a removal on the ventral side; $\mathrm{f}$ - indication of the direction of a removal on the dorsal side; $g$ - element number in refitting; $\mathrm{h}$ - negative number. 
an ellipsoid contour /e. 1, 3/ as well as a rejuvenation flake shaped by preparation of the upper striking platform /e. $2 /$.

The earliest identified sequence of procedures was connected with the preparation of the back surface. The fact that the negatives /n. 1-5/ which illustrate this process do not show preserved proximal parts suggests it happened at a very early stage. It also indicates a considerable reduction of the original dimensions of the specimen.

From this perspective, the next reconstructed stage should be called the secondary preparation. The parts subjected to this process included the surfaces of the upper striking platform /n. 6-9/ and the lower one /n. 10,11/ as well as the edge of the core $/ \mathrm{n} .12-14 /$. The aim of these procedures was to adjust the geometry of the specimen before the next stage, i.e. the process of configuration and removal of the preferential form. Its three-step course is illustrated by: negatives $/ n$. 15-18/ located along the left and right edges of the flaking surface, marks of removals /n. 20,21/ which separated the distal part of the preferential point, situated in the central portion, as well as a hinge negative left by an unsuccessful attempt at its removal /n.20,21/.

The final stage of reduction is reflected by a series of two removals intended to repair the flaking surface /n. 23, 24/ and the upper striking platform /e. 2/.

Another block, W3B10 (Figs 8; 9), is a six-part refit of a core /e. 1/, rejuvenation flake /e. 2/ and four blades /e.3-6/, which reflect the extremely complicated story of this specimen. Its "biography" can be divided into two conceptually and spatially
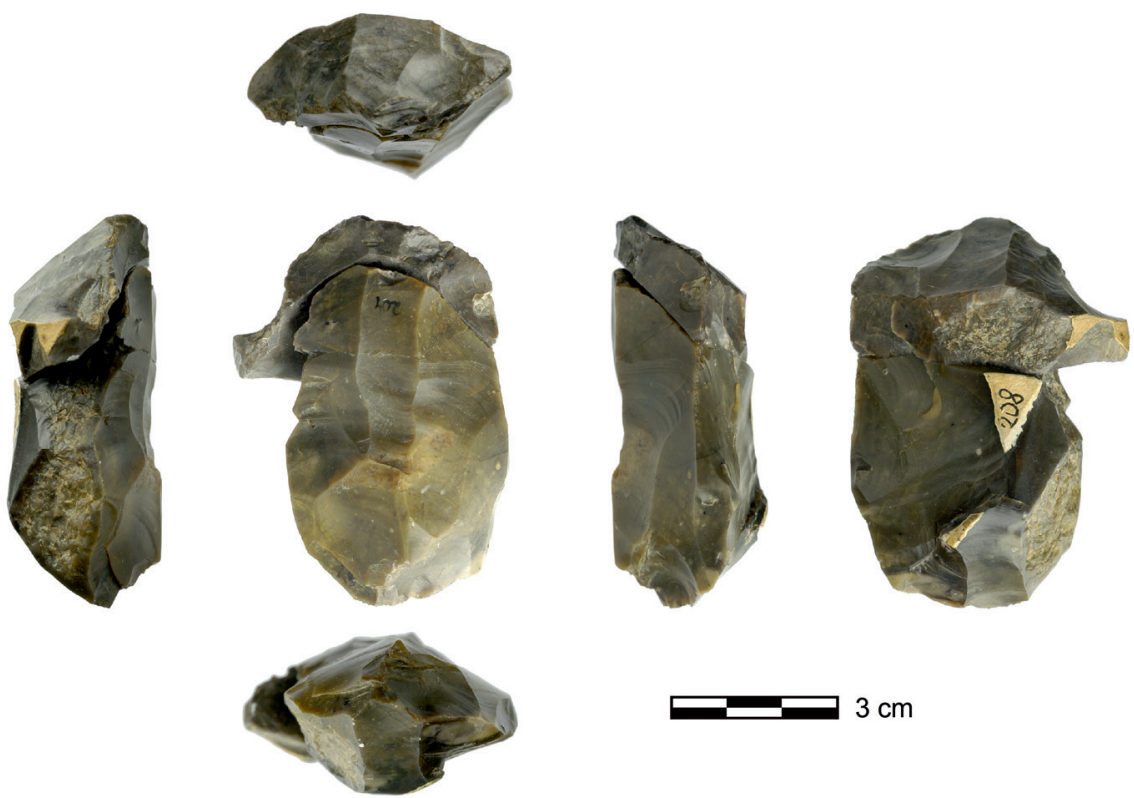

$3 \mathrm{~cm}$

Ryc. 7. Blok W3B6 - trójelementowa składanka rdzenia.

Fot. M. Przeździecki

Fig. 7. Block W3B6 - three-element refitting of a core. 
Z tej perspektywy kolejny odtwarzany etap należy określić mianem zaprawy wtórnej. Objęła ona płaszczyzny pięty górnej /n. 6-9/ i dolnej /n. 10, 11/ oraz krawędź rdzenia /n. 12-14/. Celem tych działań było wykształcenie odpowiedniej geometrii bryły warunkującej realizację następnego etapu, tj. procesu konfiguracji i oddzielenia formy preferencyjnej. Jego trójfazowy przebieg ilustrują: zlokalizowane wzdłuż prawego i lewego skraju odłupni negatywy /n. 15-18/, umiejscowione w części centralnej ślady odbić wyodrębniających wierzchołek projektowanego ostrza /n. 20, 21/ oraz zawiasowy negatyw po nieudanej próbie jego oddzielenia /n. 20, 21/.

Zapis ostatniego etapu eksploatacji dokumentuje seria dwóch odbić stanowiących naprawy odłupni /n. 23, 24/ oraz pięty górnej /e. 2/.

Kolejny blok, W3B10 (ryc. 8; 9), to sześcioelementowa składanka rdzenia /e. 1/, odnawiaka /e. 2/ i czterech wiórów /e. 3-6/, stanowiących odzwierciedlenie niezwykle
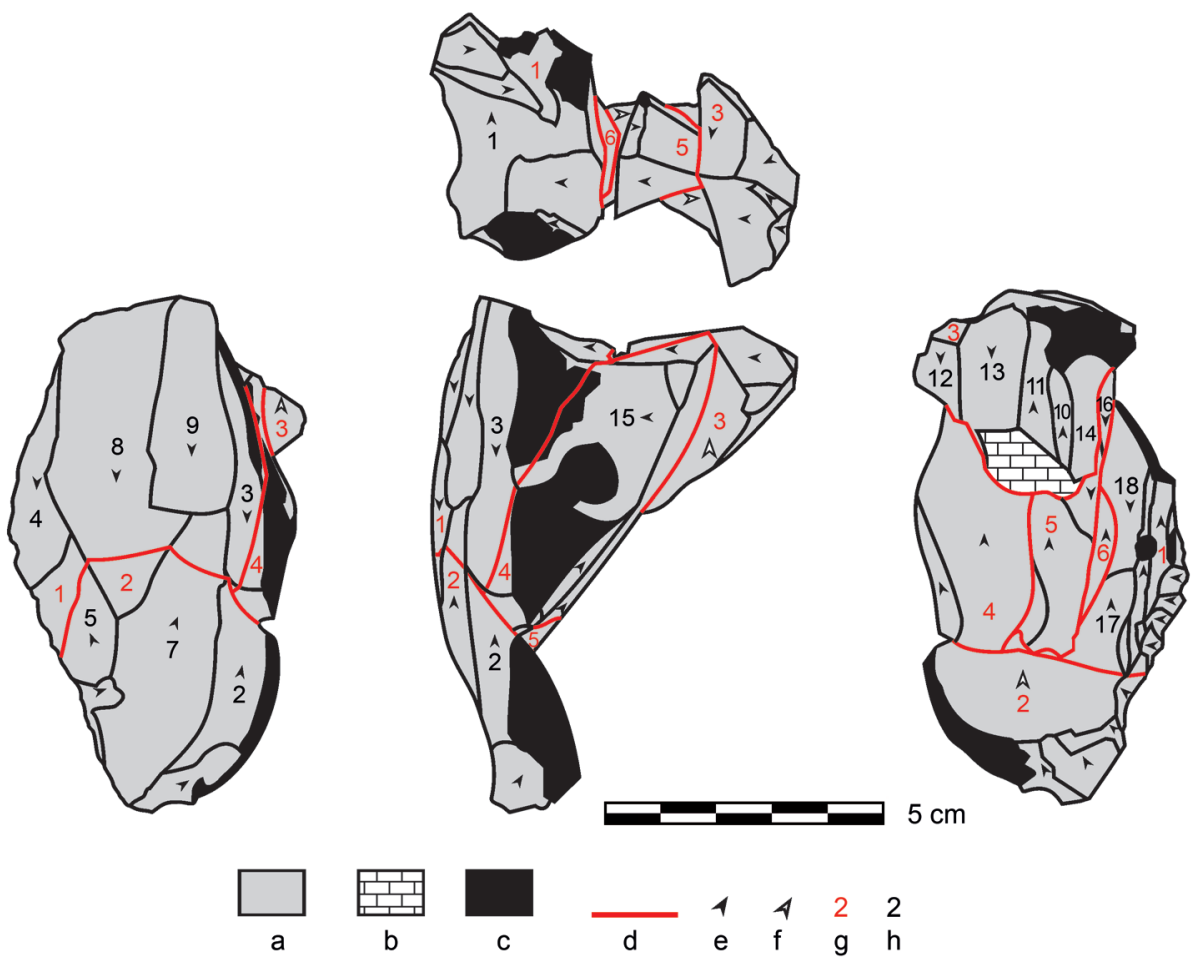

Ryc. 8. Blok W3B10

a - powierzchnie negatywów; b - powierzchnie zdegradowane (odpryski termiczne); c - powierzchnie korowe; d - linie połączeń między elementami; e - oznaczenie kierunku odbicia na powierzchni negatywowej; f - oznaczenie kierunku odbicia na powierzchni pozytywowej; g - numer elementu w składance; h - numer negatywu.

Opracował M. Przeździecki

Fig. 8. Block W3B10

$\mathrm{a}$ - surfaces of the negatives; $\mathrm{b}$ - degraded surfaces (thermal cracks); $\mathrm{c}$ - cortical surfaces; $\mathrm{d}$ - lines connecting the elements; $\mathrm{e}$ - indication of the direction of a removal on the ventral side; $\mathrm{f}$ - indication of the direction of a removal on the dorsal side; $g$ - element number in refitting; $\mathrm{h}$ - negative number. 

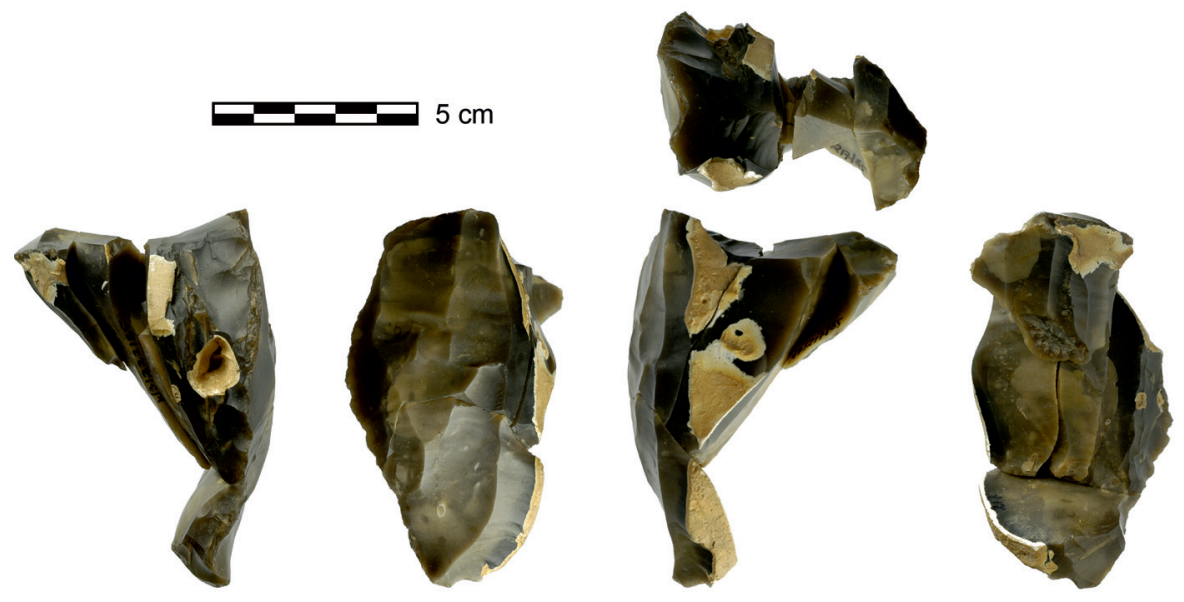

Ryc. 9. Blok W3B10 - sześcioelementowa składanka rdzenia.

Fot. M. Przeździecki

Fig. 9. Block W3B10 - six-element refitting of a core.

Photo M. Przeździecki

independent phases connected with the procedure of changing the orientation of the core. One of them is associated with the production of preferential points, the other with procurement of a series of blades /n. 9-18, e. 2-6/. From the perspective of the issues discussed in this article, the analysis of marks connected with the concept of predetermined forms is of key importance. It is reflected by the negative $/ \mathrm{n} .1 /$ on the striking platform /e. 1/ and by the pattern and sequence of removal of negatives /n. 2-9/ from the flaking surface /e. 1, 2/. The first procedure in the chaîne opératoire in this phase is defined by the preparation of the upper striking platform /n. 1, e. 1/, the lower one /e. 2/, then of the flaking surface/n. 2-4/ and the left side, which preceded the stage of generation of the point with a clear division into the step of the isolation of the edge /n. 2-5/, step of the isolation of the distal end $/ \mathrm{n} .5,7 /$ and finally the procedure of removal of the point $/ \mathrm{n}$. $8 /$. The role of the last negative $/ \mathrm{n} .9 /$ in the sequence is difficult to establish, however, it definitely closed the first phase of reduction of the core.

Analogies to these procedures and morphological attributes can be observed in the case of block W3B28 (Figs 10;11), which is a refit of a core /e. 1/ with a platform rejuvenation flake /e. $2 /$. What can be noticed first is a clearly different manner of striking platform preparation, i.e. a wide upper platform with a regular single-negative surface characterized by the angle of percussion close to $90^{\circ} / \mathrm{e} .2 /$ and a narrow lower striking platform with a limited, expediently prepared surface /n. 13/, which formed an acute angle with the flaking surface. It should be noted that the reduction of striking platforms was preceded with an intensive preparation of the back /n. 1, 2/ and the left side of the core /n. 10-12,16,17/, as well as a sequence of actions which is difficult to reconstruct and which involved reduction of the striking platform or pre-striking platform /n. 3-6/ and the flaking surface /n. 7-9/. The next phase in the 

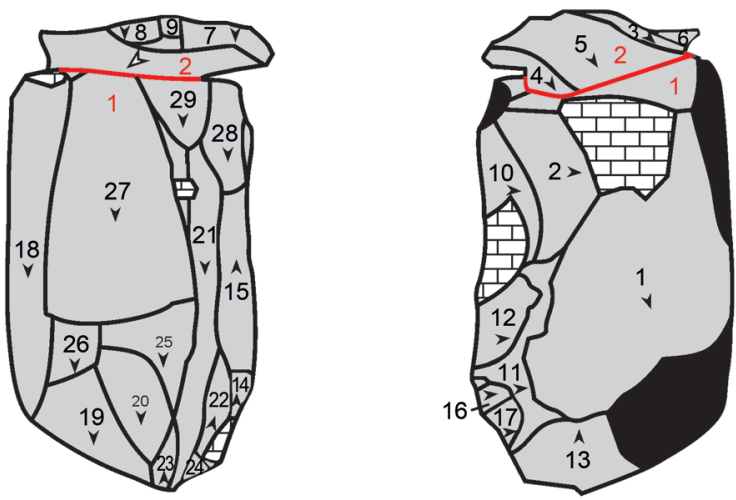

$5 \mathrm{~cm}$

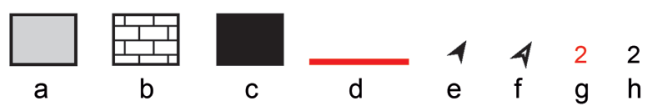

Ryc. 10. Blok W3B28

a - powierzchnie negatywów; b - powierzchnie zdegradowane (odpryski termiczne); c - powierzchnie korowe; d - linie połączeń między elementami; e - oznaczenie kierunku odbicia na powierzchni negatywowej; f - oznaczenie kierunku odbicia na powierzchni pozytywowej; g - numer elementu w składance; h - numer negatywu.

Opracował M. Przeździecki

Fig. 10. Block W3B28

$\mathrm{a}$ - surfaces of the negatives; $\mathrm{b}$ - degraded surfaces (thermal cracks); c - cortical surfaces; $\mathrm{d}$ - lines connecting the elements; $\mathrm{e}$ - indication of the direction of a removal on the ventral side; $\mathrm{f}$ - indication of the direction of a removal on the dorsal side; $\mathrm{g}$ - element number in refitting; $\mathrm{h}$ - negative number

Prepared by M. Przeździecki

skomplikowanej historii tego okazu, w którego „biografii” wydzielić możemy dwa niezależne konceptualnie i przestrzennie stadia związane z procedurą zmiany orientacji rdzenia. Pierwsze z nich łączy się z produkcją ostrzy preferencyjnych, drugie zaś z doraźnym pozyskiwaniem wiórów o charakterze seryjnym /n. 9-18, e. 2-6/. $Z$ perspektywy omawianych $\mathrm{w}$ artykule zagadnień kluczowe znaczenie ma analiza śladów związanych z koncepcją form predeterminowanych, wyrażonych przez negatyw /n. 1/ na pięcie /e. 1/ oraz w układzie i kolejności ekspozycji negatywów /n. 2-9/ na odłupni /e.1, 2/. Pierwsze ogniwo łańcucha operacji, w ramach interesującego nas stadium, definiuje zaprawa pięty górnej /n. 1, e.1/ oraz dolnej /e.2/, następnie odłupni /n. 2-4/ oraz lewego boku, poprzedzająca etap generowania ostrza z wyraźnym podziałem na fazę izolacji krawędzi /n. 2-5/, fazę izolacji wierzchołka /n. 5, 7/, a w końcu finalny zabieg oddzielenia ostrza /n. 8/. Rola ostatniego w sekwencji negatywu /n. 9/ jest trudna do określenia, niewątpliwie jednak zamyka on pierwsze stadium eksploatacji rdzenia.

Analogiczny do opisanego powyżej zestaw działań oraz atrybutów morfologicznych obserwujemy w przypadku składanki rdzenia /e. 1/ z odnawiakiem /e. 2/ oznaczonej jako blok W3B28 (ryc. 10; 11). W pierwszej kolejności uwagę zwraca 

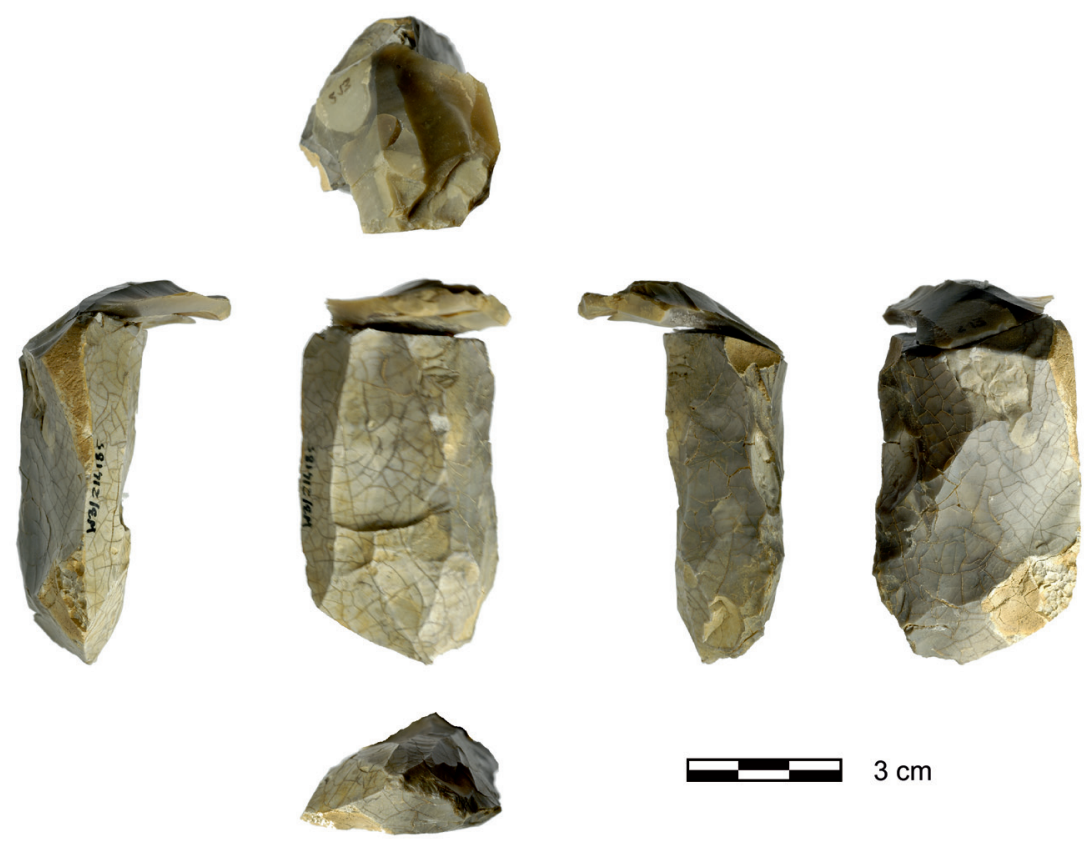

$3 \mathrm{~cm}$

Ryc. 11. Blok W3B28 - dwuelementowa składanka rdzenia.

Fot. M. Przeździecki

Fig. 11. Block W3B28 - two-element refitting of a core.

Photo M. Przeździecki

chaîne opératoire is much better documented. It was connected with the process of configuration and removal of the target form, which was achieved according to the following sequence: separation of the lateral edges /n. 15, 18-21/, separation of the distal end /n. 22-24/ and finally the removal of the point /n. 25/, in this case unsuccessful due to the formation of a hinge. The latest negatives /n. 26-29/ found on the flaking surface should be interpreted as evidence for successive attempts to separate the target form /n. 27, 29/, in both cases preceded with a reduction correcting the convexity of the flaking surface along the planned line of point removal /n. 26, 28/.

\section{DISCUSSION}

According to the author, the package of actions, consistent in terms of execution and function but at the same time a complex one, which was revealed by the analysis of the blocks (W3B1, W3B6, W3B10, W3B28), can be regarded not only as intentional, but above all as a distinctive element of the concept, assumed in advance and consistently implemented. What is particularly important, the phases of the chaîne opératoire are directly reflected in the recurrent, strictly determined morphology of the cores. 
wyraźnie odmienny sposób przygotowania pięt, tzn. szerokiej pięty górnej o równej, jednonegatywowej powierzchni charakteryzującej się kątem rdzeniowym zbliżonym do prostego /e. 2/ oraz wąskiej pięty dolnej o niewielkiej, doraźnie przygotowanej powierzchni /n. 13/, tworzącej z odłupnią kąt ostry. Warto zaznaczyć, iż zabieg ekspozycji pięt poprzedziła intensywna zaprawa tyłu /n. 1,2/ i lewego boku rdzenia /n. 10-12,16, 17/, a także trudna do rekonstrukcji grupa działań obejmujących płaszczyznę pięty lub prapięty /n. 3-6/ oraz odłupni /n. 7-9/. Znacznie lepiej udokumentowane jest kolejne ogniwo łańcucha operacji związane z procesem konfiguracji i oddzielenia formy celowej, uzyskiwanej w ramach schematu obejmującego: ekspozycje krawędzi bocznych /n. 15, 18-21/, izolację wierzchołka/n. 22-24/ oraz finalny zabieg odbicia ostrza /n. 25/, w tym przypadku nieudany ze względu na zbyt wczesne wyklinowanie wióra. Najpóźniejsze, występujące na odłupni, negatywy /n. 26-29/ należy interpretować jako świadectwo kolejnych prób odbicia formy celowej /n. 27, 29/, w obu przypadkach poprzedzone zabiegiem korygującym wypukłość odłupni wzdłuż planowanej linii oddzielenia ostrza /n. 26, 28/.

\section{DYSKUSJA}

Zdaniem autora ujawnienie w toku analizy bloków W3B1, W3B6, W3B10 i W3B28 takiego samego - zwartego wykonawczo, funkcjonalnie, a zarazem wielowątkowego - pakietu działań stanowi wystarczającą przesłankę do uznania go nie tylko za celowy, ale przede wszystkim za dystynktywny element koncepcji, z góry założonej i konsekwentnie realizowanej. Co szczególne istotne, to fakt, że poszczególne ogniwa łańcucha operacji znajdują bezpośrednie odzwierciedlenie w powtarzalnej, ściśle określonej morfologii opisywanych rdzeni.

Podsumowując wyniki przeprowadzonej analizy należy stwierdzić, że w przypadku wszystkich bloków odnotowano szerokie spektrum analogii, obejmujących: 1. cel produkcji, którym było pozyskanie jednostkowych form preferencyjnych - względnie masywnych wiórów o prostym profilu i klinowatym wierzchołku, umiejscowionym w osi symetrii wytworu; 2 . metodę produkcji (sekwencję operacji), definiowaną przez dwa zasadnicze etapy, tzn. zaprawę wstępną oraz złożony, trój- lub czterofazowy proces produkcji formy celowej, oparty na zestawie działań predeterminujących i finalnym zabiegu oddzielenia „ostrza”; 3. parametry morfologiczne, stanowiące bezpośrednie, stwierdzone w materiale źródłowym świadectwo omawianego procesu.

Zrekonstruowany - powtarzalny w przypadku wszystkich badanych bloków - zestaw działań umożliwia opracowanie zidealizowanego modelu łańcucha operacji związanych z produkcją ostrzy preferencyjnych.

Etap zaprawy ograniczał się do ekspozycji płaszczyzn dwóch, naprzeciwlegle zorientowanych, pięt oraz ewentualnej obróbki korygującej parametry tyłu lub boków rdzenia. Odłupnia była eksponowana (otwierana) przez oddzielenie serii wiórów korowych i podkorowych. Część z nich była lokalizowana w taki sposób oraz w takiej kolejności, by już na tym etapie eksploatacji uzyskać przynajmniej 
Summing up the results of the analysis, it can be concluded that in the case of all the blocks, many analogies were observed, including: 1. aim of production, i.e. the sourcing of preferential forms - relatively robust points with a straight profile and dihedral top, located along the symmetry axis of the product; 2 . method of production (chaîne opératoire) defined by two main stages, i.e. the preliminary preparation and complex, three- or four-step process of the production of the target form, based on a sequence of predetermining actions and the final removal of the "point"; 3. morphological parameters, which are the direct evidence for the described process found in the material.

The reconstructed sequence of actions, repeated in the case of all the examined blocks, makes it possible to reconstruct an idealized chaîne opératoire connected with the production of preferential points.

The stage of preparation was limited to isolation of the surfaces of two striking platforms, situated opposite each other, and possibly a correction of the parameters of the back or sides of the core. The flaking surface was isolated by removal of a series of cortical and sub-cortical blades. Some of them were located in such a way and at such a distance that it was possible already at this stage of reduction to shape at least the initial bulge of the middle part of the flaking surface, undercut on two sides by wide blade negatives (Fig. 12a).

The stage of generation of the target form involved a strictly defined sequence of actions with a clear division into the step of configuration of the predetermined form (isolation of lateral edges, distal end and sometimes also the base; Fig. 12b, c) as well as the final procedure of point removal (Fig. 12d).

Except for W3B6 refit (Figs 6; 7), marks of successive attempts at removal of the point were observed on the flaking surface if the first removal ended in failure. Some of them should be interpreted as a result of multiplication of the previously described sequence of actions, i.e. configuration and removal of points of the "second" or even "third" series (Figs 5; 12e, f).

The most distinctive morphological features of the cores associated with the described technology include:

1. The flaking surface - relatively wide, of ellipsoid or bi-conical contour and trapezoid transverse section. It is characterized by an apparently chaotic scar pattern, differing in terms of shapes, dimensions and direction of impact. The structure seems to reflect a strictly defined order of the procedures connected with the generation of target forms. Four main types of negatives can be distinguished. The first three represent the package of predetermining procedures and the fourth one - the final removal of the point. They are as follows: 1.1. negatives of reduction of the lateral edges - usually relatively wide and deep, situated at the edge of the flaking surface; 1.2. negatives of the configuration of the distal end - small ones arranged in a fan-shaped pattern. They were removed from the side of the auxiliary striking platform and are marks of the so-called correction bladelets; 1.3 . negatives of the configuration of the base - very fine, removed from the side of the main striking platform; 1.4. negatives of preferential points - relatively broad and long, reaching approx. $2 / 3$ of the height of the percussion surface. They were removed 
inicjalne wysklepienie środkowej części odłupni, podciętej z dwóch stron przez szerokie negatywy wiórowe (ryc. 12a).

Etap generowania formy celowej obejmował ściśle określoną sekwencję działań z wyraźnym podziałem na fazę konfiguracji projektowanego ostrza (izolację krawędzi bocznych, wierzchołka, a niekiedy również podstawy; ryc. 12b, c) oraz finalny zabieg oddzielenia ostrza (ryc. 12d).

Z wyjątkiem składanki W3B6 (ryc. 6; 7) na odłupniach pozostałych bloków zarejestrowano ślady kolejnych prób oddzielenia ostrza, o ile pierwsze odbicie zakończyło się niepowodzeniem. Część z nich należy interpretować jako efekt multiplikacji, omówionej wcześniej sekwencji działań, tj. konfiguracji i oddzielenia ostrzy „drugiej”, a nawet „trzeciej” serii (ryc. 5; 12e, f).

Do najbardziej dystynktywnych atrybutów morfologicznych rdzeni łączonych z opisywaną strategią technologiczną należą:

1. Odłupnia - stosunkowo szeroka o eliptycznym lub dwustożkowym zarysie i trapezowatym przekroju poprzecznym. Charakteryzuje się ona pozornie chaotycznym ułożeniem negatywów, zróżnicowanych pod względem kształtu, rozmiarów oraz kierunku odbicia. Ich struktura wydaje się odzwierciedlać ściśle określony porządek operacji związanych z generowaniem form celowych. Wyróżnić możemy cztery główne rodzaje negatywów. Trzy pierwsze reprezentują pakiet działań predeterminujących, czwarty zaś finalny - zabieg oddzielenia ostrza. Są to: 1.1. negatywy z izolacji krawędzi bocznych - zazwyczaj dość szerokie i głębokie, umiejscowione na skraju odłupni; 1.2. negatywy z konfiguracji wierzchołka - drobne o wachlarzowatym układzie, oddzielane od strony pięty pomocniczej, stanowią ślad po tzw. wiórkach korekcyjnych; 1.3. negatywy z konfiguracji podstawy - bardzo drobne, oddzielane od strony pięty zasadniczej; 1.4. negatywy ostrzy preferencyjnych - dość szerokie i długie, obejmujące około $2 / 3$ wysokości płaszczyzny odbić, oddzielane od strony pięty zasadniczej, najczęściej zlokalizowane w centralnej części odłupni.

2. Specyficzną cechą opisywanej kategorii rdzeni jest także dymorfizm pięt z podziałem funkcjonalnym na: 2.1. szeroką piętę główną, o dużej, równej powierzchni oraz szerokości zbliżonej do szerokości odłupni, umożliwiającej wykonywanie odbić w pełnym zakresie jej pola; 2.2. wąską piętę pomocniczą, o małej powierzchni i zasięgu odbić ograniczonym do środkowej części odłupni.

Jako pierwszy na istnienie form preferencyjnych w inwentarzach schyłkowopaleolitycznych zwrócił uwagę Witold Migal (2006; 2007). W pracy z $2006 \mathrm{r}$. zaproponował generalną definicję tego rodzaju wytworów oraz dokładnie wyjaśnił technologię ich pozyskiwania. Podstawę przedstawionych rekonstrukcji stanowiła, oparta na wynikach badań eksperymentalnych oraz analizie oryginalnych materiałów, koncepcja zakładająca, że uzyskanie ostrzy o określonych parametrach wymaga ściśle określonego zestawu działań produkcyjnych, tzw. predeterminujących. Co ważne, poszczególne zabiegi konfiguracyjne znajdują odzwierciedlenie w konkretnych (możliwych do identyfikacji) cechach, zarówno samych ostrzy, jak i rdzeni, od których były oddzielane, a także określonych kategoriach produktów debitażu. Niestety, precyzyjna atrybucja wiórów, wiórków, odłupków, 

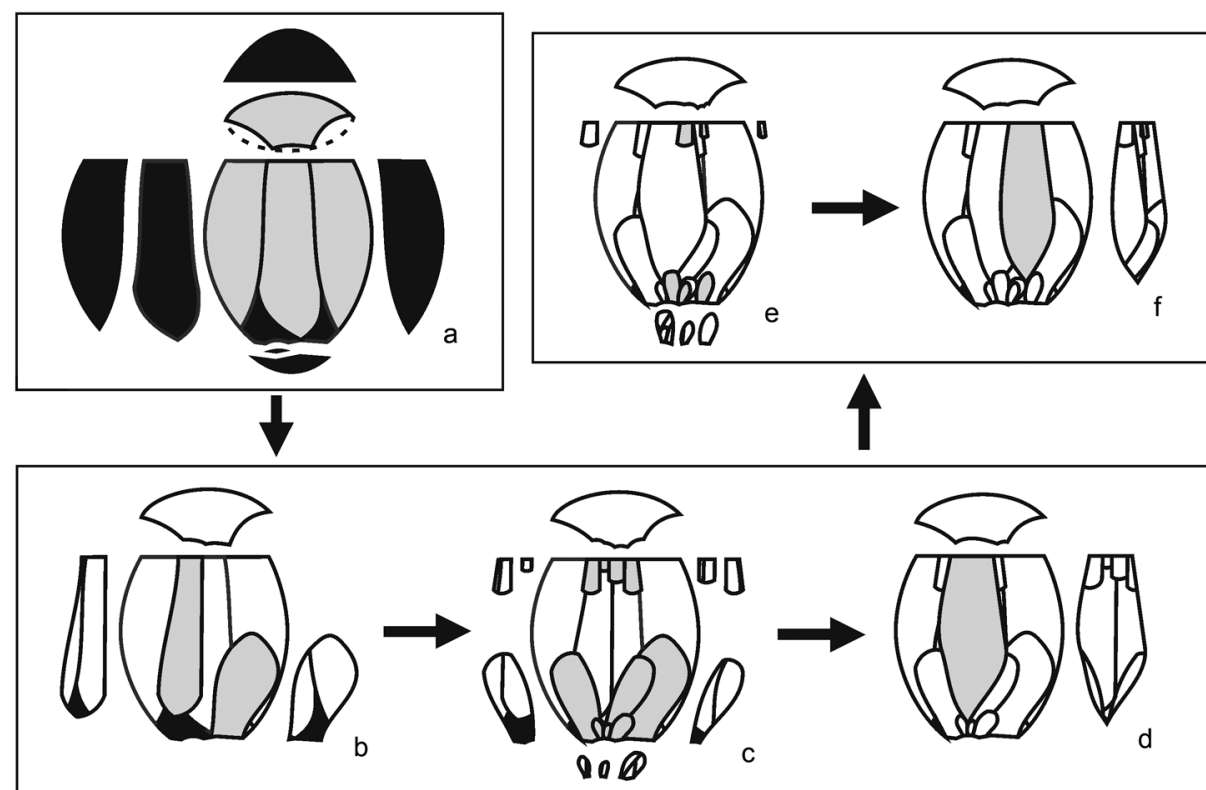

Ryc. 12. Zidealizowany schemat realizacji koncepcji produkcji ostrzy preferencyjnych a - etap pierwszy: zaprawa pięt oraz odłupni; b-d - stadium generowania ostrza „pierwszej serii”: b - izolacja krawędzi bocznych; c - izolacja wierzchołka i podstawy; $\mathrm{d}$ - oddzielenie ostrza; e, $\mathrm{f}$ - stadium generowania ostrza „drugiej serii”: e - izolacja wierzchołka i podstawy; f - oddzielenie ostrza.

Opracowali M. Przeździecki, G. Czajka

Fig. 12. Model depicting implementation of production concept of preferential points a - first phase: preparation of striking platforms and flaking platform; b-d - generating the "first series point": $\mathrm{b}$ - isolation of the lateral edges; $\mathrm{c}$ - isolation of the distal end and the bottom; $\mathrm{d}$ - separation of the point; $\mathrm{e}, \mathrm{f}$ - generating the "second series point": $\mathrm{e}$ - isolation of the distal end and the bottom; $\mathrm{f}$ - separation of the point.

Prepared by M. Przeździecki and G. Czajka

from the side of the main striking platform, usually situated in the central part of the flaking surface.

2. Dimorphism of striking platforms is a characteristic feature of this category of cores. It is characterized by a functional division into: 2.1. a wide main striking platform with a large regular surface and width close to the width of the flaking surface, which made it possible to make reductions in the whole range of its surface area; 2.2. a narrow auxiliary striking platform of a small surface area and the range of reduction limited to the middle part of the flaking surface.

Witold Migal was the first to notice preferential forms in Late Palaeolithic inventories $(2006 ; 2007)$. In the work of 2006 he proposes a general definition of this type of products and clearly explains the technology of production. The reconstructions he presents are based on his concept derived from experimental research and analysis of original material. It assumes that the production of blades of strictly defined parameters requires a strictly defined sequence of shaping actions, the so-called predetermining ones. What is important, the successive configuration procedures are reflected in particular (identifiable) features, both of the points and the cores from 
a często po prostu łusek ilustrujących kolejne fazy procesu predeterminacji jest bardzo trudna. Przykładem udanej próby tego rodzaju dywersyfikacji jest przedstawiony przez Marcina Dziewanowskiego (2004; 2006; 2012), oparty na analizie składanek i badaniach eksperymentalnych, opis materiałów kultury świderskiej ze stanowiska Dręstwo 37.

W analitycznej części artykułu starano się dowieść, że również niektóre z rdzeni odkrytych na stanowisku Wołkusz 3 (bloki W3B1, W3B6, W3B10, W3B28) odznaczają się szeregiem cech wskazujących na wyraźnie uporządkowany charakter procesu debitażu, związany z pozyskiwaniem form preferencyjnych. Ważnym argumentem potwierdzającym słuszność takiej interpretacji są ślady predeterminacji, rejestrowane w przypadku niektórych „liściaków wołkuszańskich”, w tym też w odniesieniu do co najmniej jednego okazu z badanego stanowiska.

Obserwowana dyferencjacja rozmiarów oraz proporcji liściaków może sugerować, iż przy wyborze półsurowca do ich produkcji cechy te wcale nie należały do najważniejszych. Równie istotne wydają się takie atrybuty jak: 1. prosty profil; 2. zbieżny układ krawędzi bocznych, zarówno w kierunku wierzchołka, jak i podstawy, czego efektem jest charakterystyczny liściowaty zarys. Zbyt mała różnica między szerokością wierzchołka oraz podstawy w stosunku do maksymalnej wydętości okazu powodowała, iż przybierał on kształt prostokątny lub trójkątny, co było elementem dyskwalifikującym; 3. klinowaty układ negatywów na stronie wierzchniej, stanowiących ślad po specjalnie skonfigurowanych i w odpowiedniej kolejności wyprowadzonych odbiciach; 4. daszkowaty (dwuspadowy) przekrój podłużny, związany ze zmniejszaniem się grubości ostrza w kierunku wierzchołka oraz podstawy. W modelowym ujęciu, analizując przekrój podłużny wióra zauważymy, iż jego grubość począwszy od podstawy stopniowo wzrasta, osiągając swoje maksimum mniej więcej w połowie długości okazu, po czym znów zaczyna łagodnie zmniejszać się ku wierzchołkowi; 5. trapezowaty przekrój poprzeczny, związany ze zmniejszaniem się grubości ostrza w kierunku krawędzi bocznych; 6. klinowaty wierzchołek, stanowiący efekt zbieżnego układu krawędzi bocznych oraz czytelnego w przekroju poprzecznym ścieniania się wióra w strefie wierzchołkowej. W ujęciu modelowym wierzchołek powinien wypadać dokładnie w osi symetrii półsurowiaka, choć nie był to warunek konieczny. Powszechne są ostrza o asymetrycznie położonych wierzchołkach. Przykładem skrajnego przesunięcia jego lokalizacji są liściaki, których wierzchołek znajduje się na przedłużeniu jednej z krawędzi bocznych (głównie formy z retuszowanym półtylcem).

Kompletny zestaw wymienionych powyżej cech można było uzyskać w procesie predeterminacji półsurowca, zarówno od rdzeni jedno- jak i dwupiętowych (Migal 2007).

Należy jednak wyraźnie podkreślić, iż kryteria, których kwintesencję stanowiły generowane $\mathrm{w}$ ramach procesu predeterminacji ostrza preferencyjne, $\mathrm{w}$ wielu przypadkach zaspokajały „zwykłe” wióry sytuacyjne odbijane na różnych etapach eksploatacji rdzenia. Potwierdza to przeprowadzona przez autora analiza ponad 250 liściaków bez retuszu strony spodniej trzonka z obszaru środkowej i wschodniej Polski, Litwy, Białorusi oraz Ukrainy. 
which they were removed, as well as certain categories of the debitage. Unfortunately, precise attribution of blades, bladelets, flakes and often just chips illustrating successive stages of predetermination is very difficult. The description of Sviderian culture material from site Dręstwo 37 presented by Marcin Dziewanowski (2004; 2006; 2012), based on an analysis of refits and experimental studies, is an example for a successful attempt at this type of diversification.

The intention of the analytic part of the article was to confirm that some of the cores discovered at site Wołkusz 3 (blocks W3B1, W3B6, W3B10, W3B28) display a number of features indicating a clearly ordered nature of the process of debitage connected with the production of preferential forms. The marks of predetermination detected on some "Volkushian tanged points" are an important argument corroborating the correctness of this interpretation, also with regard to at least one specimen from the site.

The observed variety in terms of dimensions and proportions among the tanged points might suggest that these features were not of highest importance for the selection of blades. Equally significant were the following: 1 . straight profile; 2 . convergent course of the lateral edges, both towards the top and the base, which resulted in a characteristic leaf-shaped form. Too small difference between the width of the top and the base in relation to the maximum convexity of the specimen made it rectangular or triangular in shape, which disqualified such a form; 3 . wedgeshaped pattern of the negatives on the dorsal surface, which was a mark of specially configured removals made in the right sequence; 4 . dihedral longitudinal section connected with the decreasing thickness of the point towards the distal end and the base. In a model case of analysis, it can be observed in the longitudinal section of the point that its thickness gradually increases starting from the base, reaches its maximum in the mid-length of the specimen and then decreases gradually towards the distal end; 5. trapezoid transverse section connected with the decrease in the thickness of the point towards the lateral edges; 6 . dihedral distal end resulting from the converging course of the lateral edges and the thinning of the blade in this area, clearly noticeable in the transverse section. In a model case, the distal end of the point should be situated precisely on the symmetry axis of the halfproduct, but this is not a critical condition. Points with an asymmetrical distal end are quite common. The example of its extreme shift can be observed in tanged points with the top situated along the course of one of the lateral edges (mainly in forms with a retouched truncation).

A complete set of the aforementioned features could be shaped in the process of predetermination of blanks, both from single- and double-platform cores (Migal 2007).

Nevertheless, it should be clearly emphasized that the criteria whose essence was reflected in preferential points generated in the process of predetermination were often met by common blades removed at various stages of reduction of the core. It is confirmed by an analysis conducted by the author, which involved examination of more than 250 tanged points without retouch on the ventral surface of the tang, discovered in central and eastern Poland, Lithuania, Belarus and Ukraine. 
Najbliższe analogie do ostrza z Wołkusza 3 znajdują się m.in. na stanowiskach: Burdeniszki 1d/e, Zusno (Szymczak 1995, tabl. XVII 1, 11), Stańkowicze I (Szmit 1929, tabl. XXX 8), Wołkusz 5 „Skupisko z liściakiem” (Szymczak 1995, tabl. XV 2), Wielka Wieś 1 (Kempisty, Sulgostowska 1991, tabl. V 7), Beršty (Obuchowski 2009, tabl. XXX 6; XXXII 1-5), Krasnasel'ski V (Obuchowski 2009, tabl. CII 1, 3, 6, 7), Bor, Krasnoselye E (Zaliznyak 1999b, ryc. 4: 1, 2, 18-23), Rudnya (Zaliznyak 1999b, ryc. 3: 5,6$)$.

Z kolei podobne formy rdzeni wystąpiły na następujących stanowiskach: Žyličy I (Białoruś): okaz quasi-dwupiętowy z podstawą doraźnie zaadoptowaną do pełnienia funkcji pięty pomocniczej. Takie atrybuty jak płaska, stosunkowo krępa odłupnia z charakterystycznym reliefem negatywów, odzwierciedlającym kompletny proces generowania formy celowej, zdają się jednoznacznie wskazywać na realizację koncepcji produkcji ostrzy preferencyjnych. Listę podobieństw dopełniają soczewkowata forma, kątowe pozbawione śladów zaprawy boki oraz płaski i całkowicie korowy tył (Obuchowski 2009, tabl. CC 2); Ežarinas 8 (Litwa): okaz dwupiętowy o płaskiej, elipsoidalnej w zarysie odłupni z charakterystycznym wielokierunkowym reliefem negatywów, kątowych bokach oraz płaskim tyle. Wystąpił w towarzystwie bogatej kolekcji rylców rdzeniokształtnych oraz krępego rylca poprzecznego (Rimantiene 1971, ryc. 60: 24); Miagiažaris 3 (Litwa): rdzeń dwupiętowy o soczewkowatej formie i płaskiej, elipsoidalnej odłupni z wielokierunkowym układem negatywów. Boki krawędziowe, tył płaski (Rimantiene 1971, ryc. 62: 3); Ust-Tudovka 1 (Ukraina): rdzeń jednopiętowy z doraźnie zaadoptowaną do pełnienia funkcji pięty pomocniczej podstawą, płaskich korowych bokach i szerokiej trapezowatej odłupni z klinowatym układem negatywów (Zaliznyak 1999a, s. 99-101, ryc. 37: 5).

\section{PODSUMOWANIE}

Zaproponowana przez Karola Szymczaka (1995, s. 13, 30, 31, 40; tenże 1999) w połowie lat dziewięćdziesiątych XX w. definicja kultury wołkuszańskiej stanowiła próbę opisu fenomenu inwentarzy charakteryzujących się współwystępowaniem liściaków z retuszem trzonka na stronę spodnią, tj. typu Świdry lub typu Chwalibogowice, oraz liściaków bez retuszu spodniej strony trzpienia, tj. nawiązujących do okazów lyngbijskich (formy masywniejsze) lub ahrensburskich (formy drobniejsze) (Taute 1968, s. 10-13, ryc. 1). Ostrzom wymienionych typów miały towarzyszyć liczne rylce, w tym o szczególnie charakterystycznych formach poprzeczne oraz rdzeniokształtne, drapacze, a także drobno retuszowane półtylczaki wiórowe (ryc. 2).

Należy podkreślić, iż na istnienie tego rodzaju inwentarzy zwracali uwagę, zarówno wcześniej, jak i później, inni badacze. Próby wyjaśnienia specyficznej koincydencji liściaków różnych typów, rejestrowanych na stanowiskach ze wschodniej części Niżu Środkowoeuropejskiego, znalazły odzwierciedlenie w takich terminach jak: "grupa Vilnius madlenu bałtyckiego” (Rimantiene 1971, s. 23-27, 32, 33), „wczesny świderien” (Szymczak 1987), „premazovien” (Schild 1988), „zespoły typu Wilno" (Sulgostowska 1989, s.61), kultura krasnosielska (Zaliznyak 1999a, 
The closest analogies to the point from Wołkusz 3 can be found at the following sites: Burdeniszki 1d/e, Zusno (Szymczak 1995, Pl. XVII 1, 11), Stańkowicze I (Szmit 1929, Pl. XXX 8), Wołkusz 5 "assemblage with a tanged point" (Szymczak 1995, Pl.XV 2), Wielka Wieś 1 (Kempisty, Sulgostowska 1991, Pl. V 7), Beršty (Obuchowski 2009, Pl. XXX 6; XXXII 1-5), Krasnasel'ski V (Obuchowski 2009, Pl. CII 1, 3, 6, 7), Bor, Krasnoselye E (Zaliznyak 1999b, Fig. 4: 1, 2, 18-23), Rudnya (Zaliznyak 1999b, Fig. 3: 5, 6).

Similar forms of cores were found at the following sites: Žyličy I (Belarus): a quasi-double platform core with the base expediently adjusted to function as an auxiliary striking platform. Features such as a flat and relatively stocky flaking surface with a characteristic scar pattern illustrating the complete process of generating the target form seem to clearly indicate the concept of production of preferential points. The list of similarities also includes a lens-like form, dihedral sides devoid of preparation marks as well as a flat and completely cortical back (Obuchowski 2009, Pl. CC 2); Ežarinas 8 (Lithuania): a double-platform specimen with a flat ellipsoid contour of the flaking surface with a characteristic multi-directional scar pattern, dihedral sides and a flat back. It was discovered in association with a rich collection of nucleiform burins and a short transverse burin (Rimantiene 1971, Fig. 60: 24); Miagiažaris 3 (Lithuania): a double-platform core of a lens-shaped form and a flat ellipsoid flaking surface with a multi-directional scar pattern; thin sides and a flat back (Rimantiene 1971, Fig. 62: 3); Ust-Tudovka 1 (Ukraine): a singleplatform core with the base expediently adjusted to function as the auxiliary striking platform, with flat cortical sides and a wide trapezoid flaking surface with a wedgeshaped scar pattern (Zaliznyak 1999a, pp. 99-101, Fig. 37: 5).

\section{SUMMARY}

The definition of the Volkushian culture, proposed by Szymczak in the mid1990s (1995, pp. 13, 30, 31 , 40; idem 1999), was an attempt at a description of a phenomenon of inventories characterized by the presence of tanged points with retouch of the tang on the ventral surface, i.e. Świdry type or Chwalibogowice type, with tanged points without retouch on the ventral surface of the tang, i.e. specimens showing analogies to Lyngby (more massive pieces) or Ahrenburg (smaller pieces) forms (Taute 1968, pp. 10-13, Fig. 1). These points were found in association with a number of burins, particularly characteristic short transversal and nucleiform, end-scrapers, as well as truncated pieces with a fine retouch (Fig. 2).

It should be emphasized that the existence of such inventories had been noticed by other scholars, both earlier and more recently. Attempts at explanation of codeposition of different types of tanged points discovered at sites in the eastern part of the North European Plain were reflected in several terms, such as "Vilnius group of the Baltic Magdalenian" (Rimantiene 1971, pp. 23-27, 32, 33), "early Sviderian" (Szymczak 1987), "pre-Mazovian" (Schild 1988), "assemblages of Vilnius type" (Sulgostowska 1989, p.61), Krasnoselye culture (Zaliznyak 1999a, pp.216-223; 
s. 216-223; tenże 1999b, s. 202-205, 211, 212), „starsze zespoły z liściakami” lub „zespoły z ostrzami ahrensburskimi” (Schild i in. 2011, s. 195, 207). Chociaż tych pojęć nie można traktować synonimicznie, różnią się bowiem w ocenie kwestii genezy oraz rangi taksonomicznej omawianego fenomenu, to jednak na poziomie opisu formalnych cech inwentarzy łączy je szereg istotnych podobieństw. Szczególnie bliska charakterystyce kultury wołkuszańskiej jest stworzona przez Romualda Schilda w połowie lat osiemdziesiątych XX w. koncepcja premazovienu (Schild 1988). Co warte podkreślenia, została ona oparta na analizie dobrze udokumentowanych, homogenicznych materiałów z poziomu V w wykopach IX oraz XI na stanowisku w Całowaniu (Schild 1975, s. 198, 276-279; por. Schild i in. 1999, s. 13-15; Schild ed. 2014). Pozycję chronologiczną tych materiałów określają daty ${ }^{14} \mathrm{C} 8870 \pm 90 \mathrm{BC} / 10820 \pm 90 \mathrm{BP}(\mathrm{GrN}-5253)$ i $8710 \pm 100 \mathrm{BC} / 10660 \pm 100 \mathrm{BP}$ (GrN-4966) uzyskane dla - zalegającej bezpośrednio nad poziomem kulturowym $\mathrm{V}$ - warstwy 6, której geneza łączona jest z pożarem roślinności w inicjalnej (prewydmowej) fazie dryasu III. Niezwykle bliskie definicji kultury wołkuszańskiej, tak pod względem charakterystyki typologicznej, datowania, jak też sposobu klasyfikacji określonych inwentarzy, jest pojęcie kultury krasnosielskiej, wyodrębnionej pod koniec XX w. przez Leonida L. Zaliznyaka (1999a, s. 216-223; tenże 1999b, s. 202-205, 211, 212).

Wspólnym mianownikiem wymienionych terminów jest fakt, że opierają się one wyłącznie na identyfikacji konkretnego zestawu form narzędziowych, pomijając charakterystykę innych wchodzących w skład analizowanych inwentarzy kategorii wytworów krzemiennych - rdzeni, wiórów lub odłupków. Efektem takiego podejścia jest dalece niedoskonała, tj. jednowątkowa, stricte typologiczna, definicja omawianego fenomenu, wykluczająca możliwość głębszej refleksji.

Zdaniem autora, zmiana tego stanu wymaga wprowadzenia argumentu nowej jakości w postaci analizy technologicznej. Stanowi ona klucz do zrozumienia rzeczywistego znaczenia poszczególnych zespołów, w tym kwestii ich genezy oraz pozycji taksonomicznej. Z tej perspektywy najistotniejsza wydaje się odpowiedź na pytanie: czy analogie rejestrowane $\mathrm{w}$ zestawie form narzędziowych znajdują odbicie także w podobnej strukturze oraz parametrach morfometrycznych produktów debitażu? Innymi słowy: czy ich specyfika typologiczna czytelna jest także w wymiarze technologicznym?

Zrekonstruowane, na podstawie rezultatów analizy materiałów ze stanowiska Wołkusz 3, strategie eksploatacyjne, w tym szczegółowo omówiona procedura produkcji ostrzy preferencyjnych, zdają się wstępnie potwierdzać tę tezę. Stanowią też pierwszy krok do dalszych badań fenomenu inwentarzy wołkuszańskich z perspektywy technologicznej. 
1999b, pp. 202-205, 211, 212), "older assemblages with tanged points" or "assemblages with Ahrensburg points" (Schild et al. 2011, pp. 195, 207). Although these designations cannot be regarded as synonymic because they differ in terms of genesis and taxonomic ranks of the phenomenon, at the level of formal features of the inventories they share a number of significant similarities. The concept of pre-Mazovian, formulated by Romuald Schild in the mid-1980s (Schild 1988), is particularly close to the characteristics of the Volkushian culture. What should be stressed, it was based on an analysis of well-documented homogeneous materials from level V in trenches IX and XI at the site in Całowanie (Schild 1975, pp. 198, 276-279; cf. Schild et al. 1999, pp. 13-15; Schild ed. 2014). The chronology of these materials was established by radio-carbon dating as $8870 \pm 90 \mathrm{BC} / 10820 \pm 90 \mathrm{BP}$ (GrN-5253) and $8710 \pm 100 \mathrm{BC} / 10660 \pm 100 \mathrm{BP}(\mathrm{GrN}-4966)$. The dating was made for bed 6 , situated directly over the cultural level $\mathrm{V}$, whose genesis is associated with a fire of vegetation in the initial (pre-dune) phase of Dryas III. The concept of the Krasnoselye culture, distinguished in the late $20^{\text {th }}$ c. by Leonid L. Zaliznyak (1999a, pp. 216-223; idem 1999b, pp. 202-205, 211, 212), is extremely close to the definition of the Volkushian culture in terms of typological characteristics, chronology and manner of classification of certain inventories.

The common denominator of the aforementioned terms is the fact that they are based exclusively on identification of a defined group of tool forms, leaving aside the characteristics of other flint artefacts in these inventories - cores, blades or flakes. As a consequence, we arrive at a very imperfect, single-aspect and strictly typological definition of the discussed phenomenon, which precludes any possibility of a more profound consideration.

In the author's opinion, a change in this respect requires an introduction of a new quality argument - technological analysis. It is the key to understanding the actual significance of particular assemblages, including the issues of their genesis and taxonomic ranks. From this perspective, it is essential to answer the question whether the analogies detected in the group of tool forms are also reflected in a similar structure and morphological parameters of the debitage products, in other words, whether their typological features correspond with the employed technology.

The reduction strategies reconstructed on the basis of the results of the analysis of the materials from site Wołkusz 3, including the procedure of preferential point production described in detail, seem to confirm this thesis. They are also the first step towards further research on the phenomenon of the Volkushian inventories, conducted from a technological perspective. 


\section{WYKAZ CYTOWANEJ LITERATURY}

\section{BIBLIOGRAPHY OF WORKS CITED}

B a r-Yos ef O., Van Peer P. 2009, The chaîne opératoire approach in Middle Paleolithic archaeology, „Current Anthropology”, 50/1, pp. 103-131.

B r a d l e y B. A., G i r i a Y. 1996, Concepts of the technological analysis of flaked stone: a case study from the High Arctic, „Lithic Technology”, 21/1, pp. 23-39.

C z i e s l a E. 1990, On reffiting of stone artefacts, [in:] The big puzzle: international symposium on refitting stone artefacts, Monrepos, 1987, E. Cziesla, S. Eickhoff, N. Arts, D. Winter eds., Studies in Modern Archaeology, 1, Bonn-Holos, pp. 9-45.

D z i e w a n o w s k i M. 2004, Świderska koncepcja organizacji przestrzeni konkrecji na przykładzie stanowiska Dręstwo 37, gm. Bargłów Kościelny, manuscript of the Master's Thesis stored in the Archive of the Institute of Archaeology, Adam Mickiewicz University, Poznań.

D zi e wa now ski M. 2006, Flint assemblage Dręstwo 37, a preliminary analysis of predetermined Swiderian debitage, [in:] The stone: technique and technology, A. Wiśniewski, T. Płonka, J.M. Burdukiewicz eds., Wrocław, pp. 149-166.

D zi e wa now ski M. 2012, On the classification of by-products of the reduction for blades - some aspects of technology in Swiderian assemblages, „Światowit”, Nowa Seria, 9/B, pp. 223-233.

Fitting rocks... 2007, Fitting rocks: lithic refitting examined, U. Schurmans, M. de Bie eds., BAR International Series, 1596, pp. 31-44.

In i z a n M. L., R o che H., T i x i e r J. 1992, Technology of knapped stone, Préhistoire de la pierre taillée, 3 , Meudon.

Ke m p ist y E., Sulgost ow ska Z. 1991, Osadnictwo paleolityczne, mezolityczne i paraneolityczne w rejonie Woźnej Wsi, woj. łomżyńskie, Sum.: Final Palaeolithic, Mesolithic and para-Neolithic settlement in the Woźna Wieś region, Łomża voivodship, Warszawa.

Migal W. 2006, On various methods of Lyngby point production, [in:] The stone: technique and technology, A. Wiśniewski, T. Płonka, J.M. Burdukiewicz eds., Wrocław, pp. 137-147.

M ig a l W. 2007, On preferential points of the Final Paleolithic in Central European Lowland, [in:] Studies in the Final Palaeolithic settlement of the Great European Plain, M. Kobusiewicz, J. Kabacinski eds., Poznań, pp. 185-200.

O b u c h ow s ki W. 2009, Materiały paleolityczne i mezolityczne z zachodniej Białorusi, Światowit Suplement Series P: Prehistories and Middle Ages, 16, Warszawa.

Pas to or s A., Tafel ma i e r Y., We n ige r G.- C. 2015, Quantification of Late Pleistocene core configurations: application of the working stage analysis as estimation method for technological behavioural efficiency, „Quartär”, 62, pp. 63-84.

Perreault C., Brantingham P.J., Kuhn S.L., Wurz S., Gao X. 2013, Measuring the complexity of lithic technology, „Current Anthropology”, 54, pp. 397-406.

Przeź d z i e c k i M. 2014, Krzemieniarstwo schyłkowopaleolitycznej kultury wołkuszańskiej $w$ świetle analizy materiałów ze stanowiska $3 w$ Wołkuszu, gm. Lipsk n/Biebrza, pow. augustowski, woj. podlaskie, manuscript of the Doctoral Dissertation stored in the Central Archive of the University of Warsaw, Warszawa.

R i m a n t i e ne R. K. 1971, Paleolit i mezolit Litvy, Vilnius.

S ch il d R. 1975, Późny paleolit, [in:] Prahistoria ziem polskich, W. Hensel ed., 1, Paleolit i mezolit, W. Chmielewski, W. Hensel eds., Wrocław-Warszawa-Kraków-Gdańsk, pp. 15-338.

S ch ild R. 1988, Processus de changemnt dans le Paléolithique Final des Plaines Septentrio- 
nales, [in:] De la Loire à l'Oder: Les civilisations du Paléolithique Final dans le Nord-Ouest Européen, M. Otte ed., Oxford, pp. 595-614.

S ch ild R. ed. 2014, Całowanie. A Final Paleolithic and Early Mesolithic site on an island in ancient Vistula channel, Warsaw.

S child R., P a z d u r M. F., Vogel J.C. 1999, Radiochronology of the tanged point technocomplex in Poland, [in:] Tanged points cultures in Europe. Read at the international archaeological symposium, Lublin, September, 13-16, 1993, S.K. Kozłowski, J. Gurba, L.L. Zaliznyak eds., Lubelskie Materiały Archeologiczne, 13, Lublin, pp. 13-15.

Schild R., Królik H., Tomaszewski A. J., Ciepielewska E. 2011, Rydno. A Stone Age red ochre quarry and socioeconomic center. A century of research, Warsaw.

Sulgost ow ska Z. 1989, Prahistoria międzyrzecza Wisty, Niemna i Dniestru, Sum.: The prehistory of the area between Vistula, Nieman and Dniestr rivers during the Final Pleistocene, Warszawa.

S z m it Z. 1929, Badania osadnictwa epoki kamienia na Podlasiu, Rés.: Recherches des colonisations de I'époque de pierre en Podlasie, „Wiadomości Archeologiczne”, 10, pp. 36-117.

S z y m c z a k K. 1987, Three faces of the Swiderian culture, [in:] New in Stone Age archaeology, J.K. Kozłowski, S.K. Kozłowski eds., Archaeologia Interregionalis, pp. 35-54.

S z y m c z a k K. 1995, Epoka kamienia Polski pótnocno-wschodniej na tle środkowoeuropejskim, Warszawa.

S z y m c zak K. 1999, Late Palaeolithic cultural units with tanged points in North Eastern Poland, [in:] Tanged points cultures in Europe. Read at the international archaeological symposium, Lublin, September, 13-16, 1993, S.K. Kozłowski, J. Gurba, L.L. Zaliznyak eds., Lubelskie Materiały Archeologiczne, 13, Lublin, pp. 93-101.

Ta u te W. 1968, Die Stielspitzen-Gruppen im nördlichen Mitteleuropa: ein Beitrag zur Kenntnis der späten Altsteinzeit, Fundamenta, A/5, Köln-Graz.

Z a l i z y a k L. L. 1999a, Finalny paleolit pivnitchnovo zahodu shidnoy Evropy, Kiev.

$\mathrm{Z}$ a l i z n y k L. L. 1999b, Tanged point cultures in western part of Eastern Europe, [in:] Tanged points cultures in Europe. Read at the international archaeological symposium, Lublin, September, 13-16, 1993, S.K. Kozłowski, J. Gurba, L.L. Zaliznyak eds., Lubelskie Materiały Archeologiczne, 13, Lublin, pp. 202-218. 
